\title{
CCAAT Enhancer Binding Protein $\delta$ Plays an Essential Role in Memory Consolidation and Reconsolidation
}

\author{
Amy A. Arguello, ${ }^{1 \star}$ Xiaojing Ye, ${ }^{2 \star}$ Ozlem Bozdagi, ${ }^{1}$ Gabriella Pollonini, ${ }^{2}$ Sophie Tronel, ${ }^{1}$ Dhananjay Bambah-Mukku, ${ }^{1}$ \\ George W. Huntley, ${ }^{1}$ Daniela Platano, ${ }^{1}$ and Cristina M. Alberini ${ }^{2}$ \\ ${ }^{1}$ Friedman Brain Institute, Mount Sinai School of Medicine, New York, New York 10029, ${ }^{2}$ Center for Neural Science, New York University, New York, New \\ York 10003, and 3'Institut National de la Santé et de la Recherche Médicale U862, 33077 Bordeaux, Cédex, France
}

\begin{abstract}
A newly formed memory is temporarily fragile and becomes stable through a process known as consolidation. Stable memories may again become fragile if retrieved or reactivated, and undergo a process of reconsolidation to persist and strengthen. Both consolidation and reconsolidation require an initial phase of transcription and translation that lasts for several hours. The identification of the critical players of this gene expression is key for understanding long-term memory formation and persistence. In rats, the consolidation of inhibitory avoidance (IA) memory requires gene expression in both the hippocampus and amygdala, two brain regions that process contextual/spatial and emotional information, respectively; IA reconsolidation requires de novo gene expression in the amygdala. Here we report that, after IA learning, the levels of the transcription factor CCAAT enhancer binding protein $\delta(\mathrm{C} / \mathrm{EBP} \delta)$ are significantly increased in both the hippocampus and amygdala. These increases are essential for long-term memory consolidation, as their blockade via antisense oligodeoxynucleotide-mediated knockdown leads to memory impairment. Furthermore, C/EBP $\delta$ is upregulated and required in the amygdala for IA memory reconsolidation. $\mathrm{C} / \mathrm{EBP} \delta$ is found in nuclear, somatic, and dendritic compartments, and a dendritic localization of $\mathrm{C} / \mathrm{EBP} \delta$ mRNA in hippocampal neuronal cultures suggests that this transcription factor may be translated at synapses. Finally, the induction of long-term potentiation at CA3-CA1 synapses by tetanic stimuli in acute slices, a cellular model of long-term memory, leads to an accumulation of $\mathrm{C} / \mathrm{EBP} \delta$ in the nucleus. We conclude that the transcription factor $\mathrm{C} / \mathrm{EBP} \delta$ plays a critical role in memory consolidation and reconsolidation.
\end{abstract}

\section{Introduction}

Memory consolidation is the process by which a newly acquired memory, which is in a labile state, becomes stable and persistent over time. This process requires de novo mRNA and protein synthesis for several hours (Davis and Squire, 1984; McGaugh, 2000; Dudai, 2004; Alberini, 2008; Helmstetter et al., 2008; Hernandez and Abel, 2008; Klann and Sweatt, 2008). After this initial consolidation phase is completed and memory has become insensitive to gene expression disruption, a reactivation event, such as memory retrieval, can again return the memory to a labile state, and another phase of de novo transcription and translation is

Received April 3, 2012; revised Dec. 19, 2012; accepted Dec. 21, 2012.

Author contributions: G.W.H. and C.M.A. designed research; A.A.A., X.Y., O.B., G.P., S.T., D.B.-M., and D.P. performed research; A.A.A., X.Y., O.B., G.P., S.T., D.B.-M., D.P., and C.M.A. analyzed data; C.M.A. wrote the paper.

This work was supported by National Institute of Mental Health Grants R01-MH065635 and R01-MH074736 to C.M.A. We thank Sarah Stern, Kuang-Fu Hsiao, and the personnel of the animal facilities of Mount Sinai School of Medicine and New York University for technical support.

The authors declare no competing financial interests.

*A.A.A. and X.Y. contributed equally to this work.

Correspondence should be addressed to Dr. Cristina M. Alberini, Center for Neural Science, 4 Washington Place, Room 809, New York, NY 10003. E-mail: ca60@nyu.edu.

A.A. Arguello's present address is Department of Psychology, University of North Carolina, Chapel Hill, North Carolina, 27599.

S. Tronel's present address is Neurocentre Magendie, Institut National de la Santé et de la Recherche Médicale U862, 33077, Bordeaux, Cédex, France.

D. Platano's present address is Laboratorio di Immunoreumatologia e Rigenerazione Tissutale, Istituto Ortopedico Rizzoli, Bologna, Italy.

DOI:10.1523/JNEUROSCI.1635-12.2013

Copyright $\odot 2013$ the authors $\quad 0270-6474 / 13 / 333646-13 \$ 15.00 / 0$ required to restabilize it. This restabilization process is known as memory reconsolidation (Lewis, 1979; Dudai and Eisenberg, 2004; Nader and Hardt, 2009; Alberini, 2011). A number of studies in the last 20 years have attempted to identify the gene expression regulators that play an essential role in memory consolidation and reconsolidation. One of the gene expression cascades found to play an evolutionarily conserved role in longterm memory formation is that controlled by the transcription factors cAMP response element binding protein (CREB) and C/EBPs. Specifically, members of both CREB and C/EBP families have been found to play an essential role in a variety of long-term plasticity and memory paradigms in invertebrates as well as mammals, where CREB appears to control the activity- or learning-dependent regulation of C/EBP expression (Alberini et al., 1995; Silva et al., 1998; Lonze and Ginty, 2002; Alberini, 2009). In mammals, the C/EBP family of transcription factors includes 6 genes that encode for several isoforms. The isoforms most abundantly expressed in the brain are $\operatorname{C/EBP} \alpha, \beta$, and $\delta$ (Lein et al., 2007), which are enriched in neurons and regulated by cAMP and $\mathrm{Ca}^{2+}$ (Alberini, 2009).

The mammalian C/EBP isoform that has been the most thoroughly investigated in learning and memory is $\mathrm{C} / \mathrm{EBP} \beta$. In previous studies, we showed that hippocampal C/EBP $\beta$ mRNA and protein are increased after inhibitory avoidance (IA) training starting between 6 and $9 \mathrm{~h}$ after training. This increase persists for $>28 \mathrm{~h}$ after training and returns to control levels by $48 \mathrm{~h}$ after training (Taubenfeld et al., 2001b). Similarly, hippocampal 
C/EBP $\beta$ expression increases after contextual fear conditioning under the control of CREB (Athos et al., 2002), and C/EBP $\beta$ is upregulated in the gustatory cortex after novel taste learning (Merhav et al., 2006). In line with its temporal profile of upregulation, hippocampal C/EBP $\beta$ plays a critical role in IA memory consolidation between 5 and $24 \mathrm{~h}$ after training (Taubenfeld et al., 2001a). C/EBP $\beta$ in the amygdala does not seem to be critically engaged during IA consolidation; however, it plays an essential role during IA reconsolidation (Tronel et al., 2005; Milekic et al., 2007), suggesting that region-specific expression regulation and functional recruitment of $\mathrm{C} / \mathrm{EBP} \beta$ occur after fear learning or retrieval.

In contrast to our understanding of the role of $\mathrm{C} / \mathrm{EBP} \beta$ in learning and memory, very little is known about the involvement of $\mathrm{C} / \mathrm{EBP} \alpha$ or $\mathrm{C} / \mathrm{EBP} \delta$. $\mathrm{C} / \mathrm{EBP} \delta$, in particular, is an interesting candidate because in several different tissues it is coregulated with and/or heterodimerizes with C/EBP $\beta$ (e.g., Cardinaux and Magistretti, 1996; Thomas et al., 2000). In line with these observations, in previous studies, we found that IA training leads to $\mathrm{C} / \mathrm{EBP} \delta$ upregulation in the same hippocampal cell population in which both CREB and C/EBP $\beta$ are sequentially induced (Taubenfeld et al., 2001b). Furthermore, a previous investigation reported an enhancement in contextual fear conditioning memory without changes in spatial memory retention in C/EBP $\delta$ knock-out mice (Sterneck et al., 1998). However, because $\mathrm{C} / \mathrm{EBP} \delta$ is critically involved in development as well as in physiological functions of several tissues (Ramji and Foka, 2002), it remains to be established whether this selective behavioral phenotype is a result of compensatory mechanisms. Thus, in the present study, we investigated the temporal profiles of C/EBP $\delta$ induction in the hippocampus and the amygdala after IA training, as well as the requirement of C/EBP $\delta$ in IA memory consolidation and reconsolidation. In addition, we examined the subcellular localization of C/EBP $\delta$ protein and mRNA in brain slices and in hippocampal neuronal cultures, and redistribution of C/EBP $\delta$ protein after long-term potentiation (LTP) induction.

\section{Materials and Methods}

Animals. Male Long-Evans rats were used for behavioral (6-8 weeks old) and LTP experiments (3-4 weeks old). Pregnant female Long-Evans rats were used to obtain embryonic day 18 (E18) rat embryos for hippocampal neuronal cultures (HNCs). Rats were individually housed in the New York University or Mount Sinai School of Medicine animal facility and maintained on a $12 \mathrm{~h}$ on/12 h off light/dark cycle with free access to food and water. For behavioral experiments, rats were handled for 3 min once a day for $4-5 \mathrm{~d}$ before the start of behavioral procedures. All protocols complied with the National Institutes of Health Guide for the Care and Use of Laboratory Animals and were approved by the New York University's and Mount Sinai's Institutional Animal Care and Use Committee.

Hippocampal and basolateral amygdala (BLA) cannulae implantation and microinjections. Rats were anesthetized with ketamine $(60 \mathrm{mg} / \mathrm{kg}$, i.p.) and xylazine $(7.5 \mathrm{mg} / \mathrm{kg}$, i.p.), and stainless steel cannulae were stereotactically implanted bilaterally to target either dorsal hippocampus (22 gauge; $4.0 \mathrm{~mm}$ posterior to bregma, $2.6 \mathrm{~mm}$ lateral from midline, and $2.0 \mathrm{~mm}$ ventral) or BLA (26 gauge; $2.8 \mathrm{~mm}$ posterior to bregma, $5.3 \mathrm{~mm}$ lateral from midline, and $6.25 \mathrm{~mm}$ ventral). After surgery, rats were allowed to recover for $7 \mathrm{~d}$. Injections of antisense oligodeoxynucleotides (ODNs) into the hippocampus ( $2 \mathrm{nmol}$ in PBS, $1 \mu \mathrm{l} /$ side) or BLA (2 $\mathrm{nmol}$ in PBS, $0.5 \mu \mathrm{l} /$ side) were performed with injection needles of 28 and 33 gauge, respectively, extending $1.5 \mathrm{~mm}$ beyond the tip of the guide cannula. Solutions were delivered with an infusion pump at a rate of 0.33 $\mu \mathrm{l} / \mathrm{min}$. Injection needles were left in place for $2 \mathrm{~min}$ after injection to allow for complete dispersion of the injected solution.

IA. IA was performed as described previously (Taubenfeld et al., 2001a; Milekic et al., 2007). The IA chamber consisted of a rectangular- shaped box, divided into a safe compartment that was white and illuminated and a shock compartment that was black and dark (Model ENV010MC, Med Associates). Foot shocks were delivered through the grid floor of the dark chamber via a constant current scrambler circuit. The IA boxes were located in a sound-attenuated, nonilluminated room. During training sessions, the rat was placed in the safe compartment. After $10 \mathrm{~s}$, the door separating the two compartments was automatically opened, allowing the rat access to enter the shock compartment. Acquisition was measured, in seconds, as the latency to enter the shock compartment. The automatic door closed $1 \mathrm{~s}$ after the rat entered the shock compartment, and a brief foot shock ( $0.9 \mathrm{~mA}$ for $2 \mathrm{~s})$ was administered. Ten seconds after the footshock, the rat was returned to the home cage. Memory retention was tested at different time points after training. During testing, the rat was placed back into the safe compartment and the latency to enter the shock compartment was recorded. No footshock was administered during retention tests and testing terminated at $540 \mathrm{~s}$. Both injections and testing were performed by investigators blind to the identity of the experimental groups.

Open field test. The locomotor activity and anxiety-like behaviors of rats were tested in an open field arena as previously described (Taubenfeld et al., 2009). Briefly, rats were placed in one corner of an open field arena $(30$ " $\times 30$ " $\times 15$ ") in a sound-attenuated, nonilluminated room. Rats' movements through the arena were videotaped for 10 min. For data analysis, the floor was divided into a grid of $4 \times 4$ squares. Locomotor activity was measured by counting the total number of the squares crossed during the testing session. The anxiety-like behaviors were measured by the number of rats' entries into the center zone (the middle $2 \times 2$ square) as well as the time spent exploring the center zone. All behavioral activities were scored by investigators blind to the experimental conditions.

Antisense ODNs. The following antisense ODNs were used: $\mathrm{C} / \mathrm{EBP} \delta$ antisense ( $\delta$-ODN: 5'-AAAGAGCGGCGCTCATGGCG-3') and scrambled control (SC-ODN: $5^{\prime}$-TACGCAGAAGCGGACTGGCG-3'). $\delta$-ODN is specific for a sequence on $\mathrm{C} / \mathrm{EBP} \delta$ mRNA that includes the translational start site but does not recognize any sequence in other $\mathrm{C} / \mathrm{EBP}$ isoforms or mammalian genes present in the GenBank database. The SC-ODN did not show any identity with relevant sequences in the GenBank database and contained the same base composition as $\delta$-ODN but in a randomized order. Both the $\delta$-ODN and SC-ODN were phosphorothioated on the 3 terminal bases on both $5^{\prime}$ and $3^{\prime}$ ends for increased stability. ODNs were reverse-phase cartridge-purified and purchased from Gene Link.

HNCs. HNCs were prepared from E18 Long-Evans rats, as previously described (Garcia-Osta et al., 2006). Briefly, pregnant female rats were killed with $\mathrm{CO}_{2}$, and embryos removed and kept on ice. Hippocampi were dissected, treated with $0.025 \%$ trypsin for $15 \mathrm{~min}$ at $37^{\circ} \mathrm{C}$ followed by trituration through a Pasteur pipette. Cells were plated on poly-Llysine-coated coverslips in minimum essential medium containing $10 \%$ horse serum. After $3-4 \mathrm{~h}$ of incubation at $37^{\circ} \mathrm{C}$ to allow cells to attach, coverslips were transferred to sterile 12 -well plates containing neurobasal medium supplemented with B-27. Plates were kept at $37^{\circ} \mathrm{C}$ with $5 \% \mathrm{CO}_{2}$ for the entire duration of culture. Cultures aged 15 DIV were used in all experiments.

Hippocampal and BLA extracts. Rats were killed by decapitation. Their brains were then quickly removed and either whole or dorsal hippocampi (as specified in the Results section) as well as BLA were dissected, pooled and snap-frozen on dry ice and stored at $-80^{\circ} \mathrm{C}$ until further use. In some experiments, BLA protein extracts were generated from brains frozen in isopentane immediately following decapitation and isolated as BLA punches using a cryostat via a neuro-punch (19 gauge, Fine Science Tools) as described previously (Milekic et al., 2007). We observed similar levels of biochemical changes in the BLA extracts prepared from either quick dissection or punches, hence the data were pooled. Both left and right sides of hippocampus or amygdala were pooled into one sample. The samples were homogenized in ice-cold lysis buffer containing protease and phosphatase inhibitors, as previously described (Taubenfeld et al., 2001b; Milekic et al., 2007).

Hippocampal slice preparation and electrophysiological recordings. Hippocampal slices $(350 \mu \mathrm{m})$ were taken from 3- to 4-week-old Long-Evans rats using a McIlwain tissue chopper. Slices were continuously perfused 
with Ringer's solution containing the following: $125 \mathrm{~mm} \mathrm{NaCl}, 2.5 \mathrm{~mm}$ $\mathrm{KCl}, 1.3 \mathrm{~mm} \mathrm{MgSO}_{4}, 1 \mathrm{~mm} \mathrm{NaH}_{2} \mathrm{PO}_{4}, 26.2 \mathrm{~mm} \mathrm{NaHCO}_{3}, 2.5 \mathrm{~mm} \mathrm{CaCl}_{2}$, $11 \mathrm{~mm}$ glucose, bubbled with $95 \% \mathrm{O}_{2} / 5 \% \mathrm{CO}_{2}$, during extracellular recordings (electrode solution: $3 \mathrm{~mm} \mathrm{NaCl}$ ). Slices were maintained for 1-2 $\mathrm{h}$ before establishment of a baseline (20-30 $\mathrm{min}$ ) of field EPSPs (fEPSPs). The temperature of the recording chamber was maintained at room temperature or at $32 \pm 1^{\circ} \mathrm{C}$ for the duration of the experiments. fEPSPs were recorded from stratum radiatum in area CA1, evoked by stimulation of the Schaffer collateral-commissural afferents every $30 \mathrm{~s}$ with bipolar tungsten electrodes with $100 \mu$ s pulses. Test stimulus intensity was adjusted to obtain fEPSPs with amplitudes that were half of the maximal response. The EPSP initial slope $(\mathrm{mV} / \mathrm{ms})$ was determined from the average waveform of four consecutive responses (Bozdagi et al., 2000). Protein synthesis-dependent late-phase LTP was induced tetanically (4 trains of $100 \mathrm{~Hz}, 1 \mathrm{~s}$ stimulation separated by $5 \mathrm{~min}$ ). Control slices received only test pulses, but no tetanic stimulation. At 15 or $45 \mathrm{~min}$ after stimulation, hippocampal slices were snap-frozen for quantitative Western blot analyses or fixed for immunohistochemical staining.

Nuclear and cytoplasmic fractions of hippocampal slices. Hippocampal slice extracts were prepared according to Ogita et al. (2002) with some modifications. Each sample included two $350-\mu \mathrm{m}$-thick hippocampal slices that were snap-frozen on dry ice and stored at $-80^{\circ} \mathrm{C}$, then thawed for $5 \mathrm{~min}$ on ice in $100 \mu \mathrm{l}$ of $10 \mathrm{~mm}$ Tris- $\mathrm{HCl}, \mathrm{pH} 7.5,0.32 \mathrm{~m}$ sucrose, 1 mм EDTA, 1 mм EGTA, $10 \mathrm{~mm} \mathrm{NaCl}, 1.5 \mathrm{~mm} \mathrm{MgCl}_{2}$ in the presence of protease and phosphatase inhibitors. The samples were homogenized with 20 strokes using a Dounce homogenizer, kept on ice for $10 \mathrm{~min}$, and then centrifuged at $3500 \mathrm{rpm}$ for $10 \mathrm{~min}$ at $4^{\circ} \mathrm{C}$. The supernatants were collected as the cytoplasmic fractions. The pellets were resuspended in $200 \mu \mathrm{l}$ of $20 \mathrm{~mm}$ Tris-HCl, pH 7.5, 0.2 mm EDTA, 0.2 mm EGTA, 20\% glycerol, $400 \mathrm{~mm} \mathrm{NaCl}, 0.5 \% \mathrm{NP}-40$ in the presence of protease and phosphatase inhibitors, incubated on ice for $30 \mathrm{~min}$, and centrifuged at $14,000 \mathrm{rpm}$ for $10 \mathrm{~min}$ at $4^{\circ} \mathrm{C}$. The resulting supernatants were taken as the nuclear fractions.

Quantitative Western blot analysis. Equal amounts of protein were resolved using denaturing SDS-PAGE and transferred to Immobilon-P membranes by electroblotting. Membranes were blocked with $5 \%$ milk and incubated with primary antibody overnight at $4^{\circ} \mathrm{C}$. All membranes were washed and incubated with HRP-conjugated secondary antibody (GE Healthcare). Quantitative densitometric analyses were done using National Institutes of Health Image J software. Actin, $\beta$-tubulin, or nuclear pore complex (NPC) was used for sample normalization, and data were expressed as mean percentage \pm SEM of the respective control group as specified in Results. Primary antibodies: anti-C/EBP $\delta$ (Cell Signaling Technology; catalog \#2318, 1:1000), anti-C/EBP $\beta$ (C-19, Santa Cruz Biotechnology; catalog \#sc-150, C-19, 1:1000), anti-actin (Santa Cruz Biotechnology; catalog \#sc-1616, 1:50,000), anti- $\beta$-tubulin (Millipore; catalog \#05-661, 1:100,000), and anti-NPC (mAB414, Abcam; catalog \#ab24609, 1:5000).

$C / E B P \delta$-maltose-binding-protein $(M B P)$ fusion protein and competitions. Recombinant $\mathrm{C} / \mathrm{EBP} \delta$ used for competition experiments was produced as full-length C/EBP $\delta$-MBP fusion protein $(\delta$-MBP) using the pMAL protein fusion and purification system from New England Biolabs, according to the manufacturer's protocol. For competition experiments in Western blot, anti-C/EBP $\delta$ antibody was preincubated with $200 \times$ excess of $\delta$-MBP or MBP in TBS with $0.1 \%$ Tween- 20 and $0.5 \%$ BSA for $2 \mathrm{~h}$ at room temperature before applied to the membranes. For competitions experiments with immunocytochemistry, $20 \times$ excess of $\delta$-MBP or MBP was used.

Immunohistochemistry. Rats were anesthetized with pentobarbital $(100 \mathrm{mg} / \mathrm{kg})$ and then perfused transcardially with ice-cold $0.1 \mathrm{M}$ PBS for $3 \mathrm{~min}$ followed by $4 \%$ PFA for $15 \mathrm{~min}$ at a flow rate of $9 \mathrm{ml} / \mathrm{min}$. Brains were postfixed overnight in $4 \%$ PFA, followed by a $2-3 \mathrm{~d}$ cryoprotection in $30 \%$ sucrose $/ \mathrm{PBS}$ at $4^{\circ} \mathrm{C}$. Serial sets of $30 \mu \mathrm{m}$ coronal sections from fixed brains were collected on a freezing microtome and mounted on slides. For immunocytochemistry of hippocampal cultures, cells were fixed with 2\% PFA in PBS for $30 \mathrm{~min}$ at room temperature, followed by $\mathrm{PBS}$ rinses. Fixed sections or cultures were incubated in blocking solution (3\% serum, $0.3 \%$ Triton X-100), followed by incubation with primary antibody overnight in $3 \%$ serum, $0.3 \%$ Tween 20 , and subsequent incu- bation with a AlexaFluor- 488 conjugated secondary antibody. Protein induction was observed throughout the anterior posterior axis of the hippocampus; therefore, representative sections were chosen for quantification of immunofluorescence. Fluorescence intensity was quantified from fluorescent microscopy images, as previously described (Tsokas et al., 2005). Briefly, the mean fluorescence intensity was quantified from four $30 \mu \mathrm{m}$ brain sections/group (naive, unpaired, and trained) taken equidistant between -3.2 to $-3.4 \mathrm{~mm}$ from bregma (hippocampus) and -2.4 to $-2.6 \mathrm{~mm}$ from bregma (amygdala). The mean fluorescence intensity of positive immunostaining was normalized to the mean intensity of regions that showed a background level of immunostaining. Primary antibodies were as follows: anti-C/EBP $\delta$ (Santa Cruz Biotechnology; catalog \# sc-151, C-22, 1:1000) and anti-MAP2 (Millipore; catalog \#MAB3418, 1:2000).

FISH. FISH was performed as previously described (Guzowski and Worley, 2001; Garcia-Osta et al., 2006) with some modifications. Digoxigenin (DIG)-labeled antisense and sense riboprobes were generated by in vitro transcription from a $200 \mathrm{bp}$ C/EBP $\delta$ PCR product adapted with T3 and T7 RNA polymerase binding sites, respectively (antisense primer: 5'-TAA CCC TCA CTA AAG GGA CAG TCT CTT CCT CTT ATC TA-3'; sense primer: 5' -TAA TAC GAC TCA CTA TAG GGG GCA CTG GAC TGC GAG AGA A-3'). Coronal $(20 \mu \mathrm{m})$ sections from fixed brains were collected on a Cryostat and mounted on slides. Before hybridization, these sections underwent pretreatment steps, including proteinase $\mathrm{K}$ digestion, acetylation, and permeabilization. For FISH on HNCs, cell also underwent all pretreatment steps, except proteinase K digestion. Afterward, brain sections/HNCs were incubated with hybridization buffer $(50 \%$ formamide, $5 \times$ SSC, $50 \mathrm{mg} / \mathrm{ml}$ dextran sulfate, $250 \mu \mathrm{g} / \mathrm{ml}$ yeast tRNA, $500 \mu \mathrm{g} / \mathrm{ml}$ salmon sperm DNA, $1 \times$ Denhardt's solution) for 30 min, and hybridized with denatured DIG-labeled antisense or sense riboprobes (brain sections, $2.0 \mathrm{ng} / \mathrm{ml}$; HNCs, $0.5 \mathrm{ng} / \mathrm{ml}$ ) at $58^{\circ} \mathrm{C}$ overnight in a humidified chamber. The next day, brain sections/HNCs were treated with $10 \mu \mathrm{g} / \mathrm{ml}$ RNase A at $37^{\circ} \mathrm{C}$ for $30 \mathrm{~min}$ and washed with $2 \times$ SSC and $0.2 \times$ SSC. Brain sections/HNCs were then incubated with $3 \%$ $\mathrm{H}_{2} \mathrm{O}_{2}$ for 15 min and $0.5 \%$ blocking buffer powder (PerkinElmer Health Sciences) dissolved in Tris-saline buffer for $1 \mathrm{~h}$, followed by incubation with anti-DIG POD antibody (Roche Applied Science; catalog \#11207733910, 3 $\mathrm{U} / \mathrm{ml}$ ) and anti-MAP2 antibody (Millipore; catalog \#MAB3418, 1:200) overnight at $4^{\circ} \mathrm{C}$. On day 3 , anti-DIG POD was detected with CY3-tyramide signal amplification (PerkinElmer Health Sciences), and anti-MAP2 antibody was detected with AlexaFluor-647-conjugated secondary antibody. Samples were imaged on a confocal microscope, with identical settings used for acquiring images of brain sections/HNCs treated with sense and antisense riboprobes.

Statistical analyses. Data are reported as mean \pm SEM. Statistical analyses were performed using one-way ANOVA followed by Bonferroni post hoc tests for selected groups. For paired comparisons, Student's $t$ test was used. All statistical analyses were performed using Prism Version 5.0 software.

\section{Results \\ $\mathrm{C} / \mathrm{EBP} \delta$ protein expression is increased in the hippocampus after IA training}

In previous studies, we have reported that $\mathrm{C} / \mathrm{EBP} \delta \mathrm{mRNA}$ is significantly increased in the rat hippocampus at 20 but not at 3, 6, 9, or $72 \mathrm{~h}$ after IA training and that $\mathrm{C} / \mathrm{EBP} \delta$ protein is present in the same cell population in which both phosphorylation of CREB at Ser 133 and C/EBP $\beta$ is induced (Taubenfeld et al., 2001b). Here, we first determined whether hippocampal C/EBP $\delta$ protein levels were upregulated after IA training using both Western blot and immunohistochemistry. To verify that the commercial anti-C/ $\mathrm{EBP} \delta$ antibodies that we purchased were indeed specific for $\mathrm{C} / \mathrm{EBP} \delta$ in the rat brain, we performed antibody competition tests. A recombinant $\mathrm{C} / \mathrm{EBP} \delta$-MBP fusion protein $(\delta$-MBP) was constructed using a pMAL fusion plasmid (New England Biolabs). Western blots of $\delta$-MBP (20 ng) or hippocampal extracts $(30 \mu \mathrm{g})$ from naive rats were stained using the anti-C/EBP $\delta$ an- 
A



\section{B WHOLE HIPPOCAMPUS}

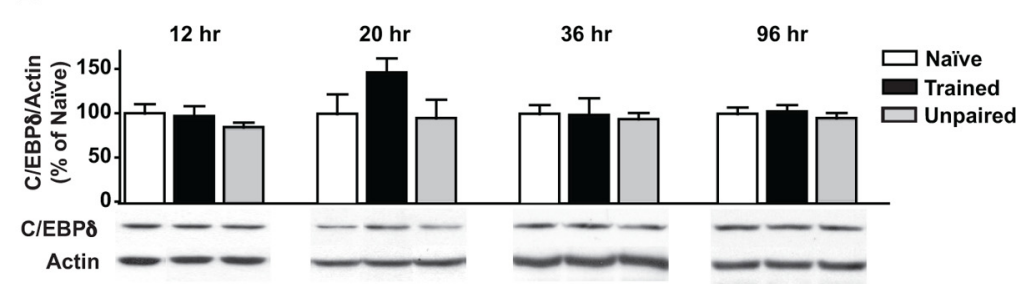

C DoRsal hippocampus

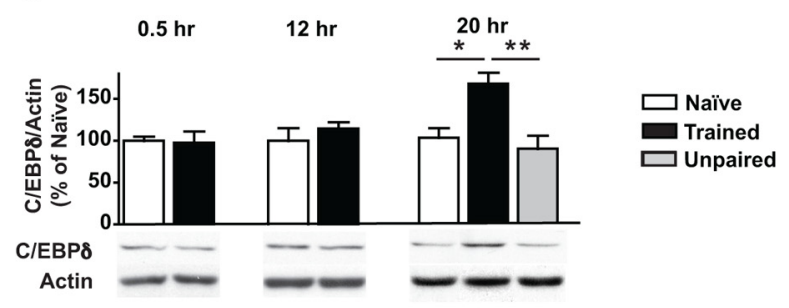

D
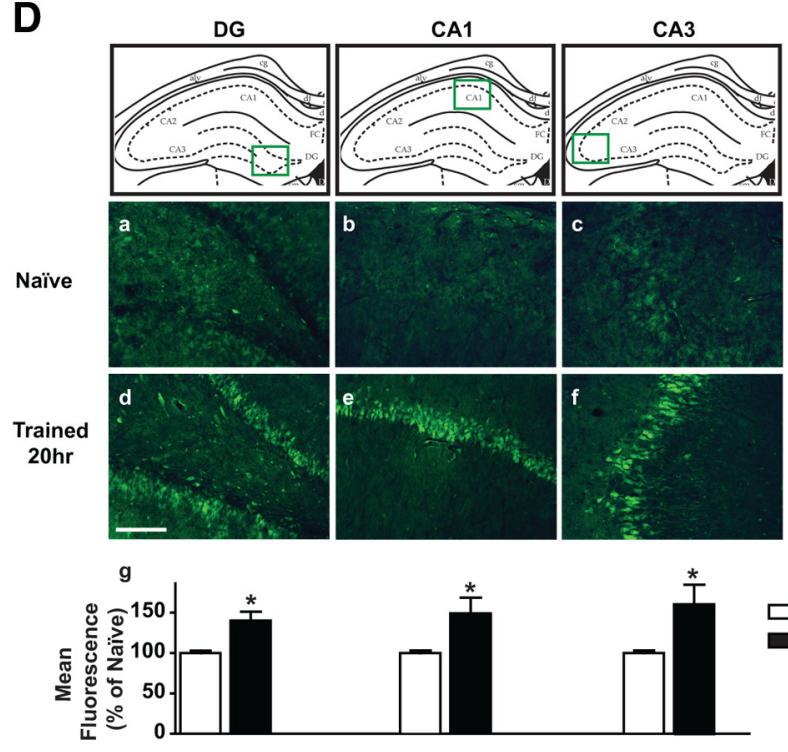

Figure 1. Hippocampal C/EBP $\delta$ level is increased after IA training. $A$, Validation of C/EBP $\delta$ antibody specificity for Western blotting. Western blot immunostaining of hippocampal extracts $(\mathrm{H})$ or recombinant CEBP $\delta$-MBP $(\delta$-MBP, R) incubated with C/EBP $\delta$ antibody in the presence of $200 \times$ excess of either $\delta$-MBP or MBP. Both the $29 \mathrm{kDa}$ band in $\mathrm{H}$ and the $75 \mathrm{kDa} \delta$-MBP in R were competed by $\delta$-MBP but not MBP. $B$, Densitometric analysis of C/EBP $\delta$ in whole hippocampal extracts via quantitative Western blotting, with representative blots shown below each graph. Rats were trained and killed at different time points after training. C/EBP $\delta$ levels remain unchanged at 12,36 , or $96 \mathrm{~h}$ after training compared with naive or unpaired controls. However, a trend toward an increase was seen at $20 \mathrm{~h}$ after training (naive, $n=3$ or 4 ; unpaired, $n=4$ or 5 ; trained, $n=4$ or 5 for all time points). Data are expressed as mean percentage \pm SEM of naive (100\%) control mean values. C, Densitometric analysis of C/EBP $\delta$ in dorsal hippocampal extracts with representative blots shown below each graph. C/EBP $\delta$ levels were significantly increased at $20 \mathrm{~h}$ after training compared with naive and unpaired controls. ${ }^{*} p<0.05 .{ }^{* *} p<0.01$. No change was found at 0.5 or $12 \mathrm{~h}$ after training (naive, $n=5$ or 6 ; unpaired, $n=4-6$; trained, $n=4-6$ for all time points). Data are expressed as mean percentage \pm SEM of naive (100\%) control mean values. D, Immunofluorescence of C/EBP $\delta$ staining. Schematic representations of the areas shown in the pictures are indicated in the green boxes. Examples of DG, $C A 1$, and CA3 of naive $(\boldsymbol{a}-\boldsymbol{c})$ and trained rats $(\boldsymbol{d}-\boldsymbol{f})$ showing an induction of C/EBP $\delta 20 \mathrm{~h}$ after training ( $n=4 /$ group). $\boldsymbol{g}$-i, Quantitative mean fluorescence analysis revealed a significant increase in C/EBP $\delta$ in all subregions. Scale bar, $100 \mu \mathrm{m}$. tibody in the presence or absence of an excess of $\delta$-MBP or MBP. As shown in Figure $1 A, 200 \times$ excess of $\delta$-MBP eliminated the recognition by the antibody of both $\delta$-MBP $(75 \mathrm{kDa})$ and the $29 \mathrm{kDa}$ band in the hippocampal extract, which corresponds to the correct molecular weight for $\mathrm{C} / \mathrm{EBP} \delta$ (Cao et al., 1991), whereas the same amount of MBP had no effect on antibody binding. Hence, this antibody was used to perform quantitative Western blot analyses of $\mathrm{C} / \mathrm{EBP} \delta$ expression after IA training. Whole hippocampal extracts (including both dorsal and ventral hippocampus) were obtained from naive rats and rats trained in IA and killed at 12, 20, 36, or $96 \mathrm{~h}$ after training. As shown in Figure $1 B$, there was a trend for increased $\mathrm{C} / \mathrm{EBP} \delta$ levels at $20 \mathrm{~h}$ after training; however, an ANOVA across all time points showed that this change was not significant. We then restricted our investigations to the dorsal hippocampus, a region known to process contextual information and in which we previously observed significant molecular changes after IA (Chen et al., 2011, Chen et al., 2012). Hence, we used quantitative Western blot analyses to determine whether $\mathrm{C} / \mathrm{EBP} \delta$ expression in dorsal hippocampus changed at $0.5,12$, and $20 \mathrm{~h}$ after training (Fig. 1C). We found that $\mathrm{C} / \mathrm{EBP} \delta$ levels were significantly increased at $20 \mathrm{~h}$ after training $(165.6 \pm 13.9 \%)$ compared with naive $(100 \pm 11.7 \%, p<0.05)$ but remained unchanged at 0.5 and $12 \mathrm{~h}$ after training, consistent with our earlier findings that $\mathrm{C} / \mathrm{EBP} \delta$ mRNA level was increased at $20 \mathrm{~h}$ but not at earlier time points after IA training (Taubenfeld et al., 2001b). Furthermore, to examine whether the increase in $\mathrm{C} / \mathrm{EBP} \delta$ levels at the $20 \mathrm{~h}$ time point is specific to the associative aspect of IA memory, we also included an unpaired control group for this time point. This unpaired group consisted of rats that were exposed to the training apparatus without receiving any shock and, an hour later, were placed on the footshock grid, received immediately a footshock, and were then returned to their home cage. The unpaired context shock does not evoke any IA memory and controls for both context and shock experience within subject (Garcia-Osta et al., 2006; Chen et al., 2011). We found that, $20 \mathrm{~h}$ after IA training, C/EBP $\delta$ levels were significantly increased compared with those of the unpaired controls (86.8 \pm $16.1 \%, p<0.01)$, which, in turn, were not significantly different from those of the naive group (one-way ANOVA, $F_{(2,15)}=$ $8.821, p=0.003$; followed by Bonferroni's post hoc test). 


\section{HIPPOCAMPUS}
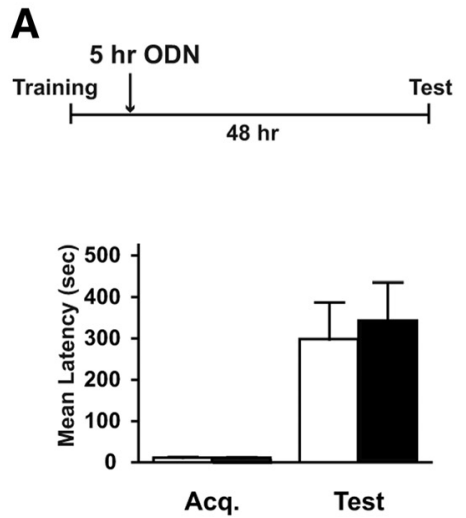
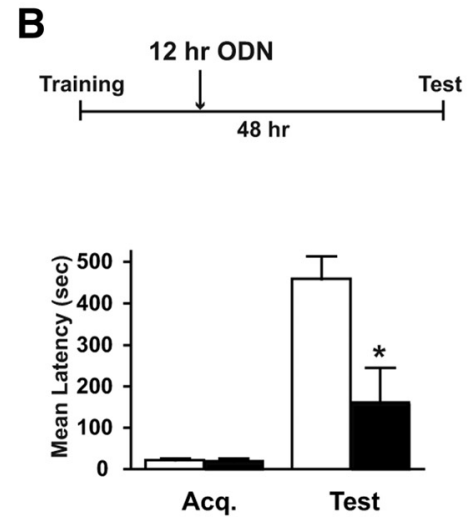

SC-ODN
C
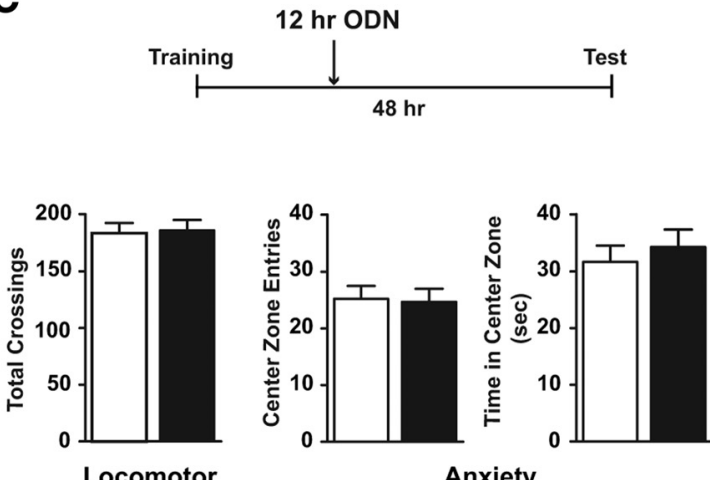

Figure 2. Hippocampal C/EBP $\delta$ protein is required for the consolidation of IA memory. $\boldsymbol{A}$, Rats were injected with SC-0DN or $\delta$-0DN $5 \mathrm{~h}$ after training and tested $48 \mathrm{~h}$ after training. Memory retention was comparable in both groups $(n=7$ or 8 ). Retentions are expressed as mean latency \pm SEM in seconds. $B$, Rats injected with $\delta$-0DN $12 \mathrm{~h}$ after training showed a significant memory impairment compared with SC-ODN-injected rats at $48 \mathrm{~h}$ after training $\left(n=8 /\right.$ group). ${ }^{*} p<0.05$. Retentions are expressed as mean latency \pm SEM in seconds. $C$, Rats injected with $\delta$-0DN $12 \mathrm{~h}$ after training showed no difference in locomotor activity and anxiety-like activity, measured by entries into and time spent in the center zone, compared with SC-0DN-injected rats in the open field test at $48 \mathrm{~h}$ after training ( $n=8$ or $9 /$ group).

To confirm the training-dependent increase of C/EBP $\delta$ and investigate its regional distribution, we examined the expression of $\mathrm{C} / \mathrm{EBP} \delta$ levels in dorsal hippocampus in naive and trained rats using immunohistochemistry performed with a different $\mathrm{C} / \mathrm{EBP} \delta$ antibody (see Materials and Methods). The specificity of the antibody was confirmed by competition tests (see Fig. $4 B$ ). An increase in immunoreactivity was observed throughout the anterior-posterior axis of the hippocampal subregions, including dentate gyrus (DG), CA1, and CA3 of trained rats compared with naive rats (Fig. $1 D$ ). Quantification of mean immunofluorescence intensity between naive and trained groups and Student's $t$ tests revealed a significant increase in mean fluorescence intensity $20 \mathrm{~h}$ after training in each subregion (Fig. $1 D$ : DG, naive $=100 \pm 3.1 \%$, trained $=140 \pm 11.0 \%, p<$ 0.05 ; CA1, naive $=100 \pm 3.5 \%$, trained $=149 \pm 19.4 \%, p<0.05$; $\mathrm{CA} 3$, naive $=100 \pm 3.5 \%$, trained $=160.5 \pm 24.5 \%, p<0.05)$.

Together, these results indicate that IA training leads to a significant and widely distributed increase in $\mathrm{C} / \mathrm{EBP} \delta$ protein levels in the dorsal hippocampus $20 \mathrm{~h}$ after IA training.

\section{Hippocampal C/EBP $\delta$ is required for the consolidation of IA memory}

Given that $\mathrm{C} / \mathrm{EBP} \delta$ protein is increased in the dorsal hippocampus after training, we asked whether this induction plays a role during the consolidation of IA memory. To block the induction of $\mathrm{C} / \mathrm{EBP} \delta$, we injected antisense ODN against $\mathrm{C} / \mathrm{EBP} \delta$ into the dorsal hippocampus. Previous studies have established that an ODN injection into the dorsal hippocampus targets and remains largely confined to this region and that the ODN is present for a restricted temporal window after injection (i.e., readily detected at $2 \mathrm{~h}$ but not at $8 \mathrm{~h}$ after injection) (Taubenfeld et al., 2001a; Garcia-Osta et al., 2006; Suzuki et al., 2011).

To determine the selectivity and effectiveness of the ODNdependent knockdown of $\mathrm{C} / \mathrm{EBP} \delta$, rats were stereotaxically implanted bilaterally with cannulae targeting the dorsal hippocampus, trained in IA, and, $12 \mathrm{~h}$ after training, received a bilateral injection of antisense ODN specific for $\mathrm{C} / \mathrm{EBP} \delta(\delta$ ODN) or a scrambled, control ODN (SC-ODN). This $12 \mathrm{~h}$ time point was chosen based on our finding that $\mathrm{C} / \mathrm{EBP} \delta$ was induced in dorsal hippocampus between 12 and $20 \mathrm{~h}$ after IA training (Fig. 1C). Twenty hours after training, the rats were killed and protein extracts were obtained from their dorsal hippocampi and probed for $\mathrm{C} / \mathrm{EBP} \delta$ expression using quantitative Western blot analyses. $\delta$-ODN significantly decreased $\mathrm{C} / \mathrm{EBP} \delta$ expression levels by $24 \%$ (SC-ODN, $100.0 \pm 7.6 \%$; $\delta$-ODN, $76.2 \pm 5.5 \%, n=7$ or $8 ; p<0.05$, Student's $t$ test), a decrease that corresponded to the blockade of the traininginduced increase in $\mathrm{C} / \mathrm{EBP} \delta$ expression (see Fig. 1C). Furthermore, the knockdown effect was specific to $\mathrm{C} / \mathrm{EBP} \delta$, as $\mathrm{C} / \mathrm{EBP} \beta$ levels remained unchanged in the same extracts (SCODN, $100.0 \pm 17.5 \% ; \delta$-ODN, $91.3 \pm 14.2 \%$,). Hence, we tested the effect of bilateral $\delta$-ODN injections on memory retention. Rats were trained in IA, and 5 or $12 \mathrm{~h}$ after training, received a bilateral injection of SC-ODN or $\delta$-ODN into the dorsal hippocampus. Forty-eight hours after training, they were tested for memory retention. As shown in Figure $2 \mathrm{~A}$, $\delta$-ODN injections $5 \mathrm{~h}$ after training had no effect on memory retention compared with SC-ODN injected controls $(\delta$-ODN, $343 \pm 93.0 \mathrm{~s} ;$ SC-ODN, $298 \pm 89.9$ s), suggesting that the $\delta$-ODN injection by itself, at a time point at which there was no training-induced increase in $\mathrm{C} / \mathrm{EBP} \delta$ expression, had no nonspecific effects on memory retention and expression. However, $\delta$-ODN injections at $12 \mathrm{~h}$ after training, which just precedes the C/EBP $\delta$ induction, significantly disrupted memory retention $(161 \pm 83.9 \mathrm{~s})$ compared with SC-ODN controls $(459 \pm 55.2 \mathrm{~s})$ (Fig. $2 B ; p<0.05$, Student's $t$ test). In addition, $\delta$-ODN injection at $12 \mathrm{~h}$ after training did not change locomotor activity measured by total number of squares crossed (SC-ODN, $183.1 \pm 9.1 ; \delta$-ODN, $185.8 \pm 9.1$ ), or the anxietylike behavior measured by entries into the center zone (SCODN, $25.2 \pm 2.3 ; \delta$-ODN, $24.7 \pm 2.3)$ and time spent in the center zone (SC-ODN, $31.7 \pm 2.8 \mathrm{~s} ; \delta$-ODN, $34.2 \pm 3.1 \mathrm{~s}$ ) in an open field test at $48 \mathrm{~h}$ after training (Fig. $2 \mathrm{C}$ ).

Together, these results indicate that inhibiting the traininginduced increase in $\mathrm{C} / \mathrm{EBP} \delta$ levels in the dorsal hippocampus impairs the consolidation of IA memory. 


\section{The expression of $\mathrm{C} / \mathrm{EBP} \delta$ is increased in the BLA by IA training and required for memory consolidation and reconsolidation}

Previous studies from our laboratory have shown that, although new protein synthesis is required in both hippocampus and amygdala for IA memory consolidation, the role of $\mathrm{C} / \mathrm{EBP} \beta$ in these two regions is fundamentally distinct: $\mathrm{C} / \mathrm{EBP} \beta$ plays an essential role during the first day after training during the consolidation of IA memory in the hippocampus but not in the amygdala (Taubenfeld et al., 2001a; Milekic et al., 2007). Here, we asked whether $\mathrm{C} / \mathrm{EBP} \delta$ protein expression changes in the amygdala after IA training. We used quantitative Western blot analyses to examine the time course of $\mathrm{C} / \mathrm{EBP} \delta$ levels in the BLA after IA training. BLA extracts were obtained from naive rats and rats trained in IA and killed at $0.5,6,9,20$, or $48 \mathrm{~h}$ after training. As shown in Figure $3 A$, there was a significant increase in C/EBP $\delta$ levels at $9 \mathrm{~h}(172.8 \pm 26.6 \%, p<0.001)$ and $20 \mathrm{~h}(128.1 \pm 4.1 \%$, $p<0.05)$ after training compared with those of naive rats $(100 \pm$ $2.43 \%)$, but no significant changes at other time points $(0.5 \mathrm{~h}$ : $87.3 \pm 6.5 \%$; 6 h: $94.1 \pm 3.1 \%$; 48 h: $84.5 \pm 6.0 \%)$. In addition, we found that the increase in $\mathrm{C} / \mathrm{EBP} \delta$ levels at $9 \mathrm{~h}$ after training was specific to the contextual fear association because there was no change in $\mathrm{C} / \mathrm{EBP} \delta$ levels in the BLA of unpaired rats (104.3 \pm $8.8 \%, p<0.001$, compared with the trained 9 h group; one-way ANOVA, $F_{(6,75)}=12.0, p<0.001$; followed by Bonferroni's post hoc test).

To verify and extend these findings, we used immunohistochemistry to examine $\mathrm{C} / \mathrm{EBP} \delta$ levels in BLA of naive, unpaired, and trained rats at $20 \mathrm{~h}$ after training. As shown in Figure $3 B$, a significant increase in fluorescence intensity was observed in the BLA of trained rats compared with that of naive and unpaired controls (one-way ANOVA, $\left(F_{(2,9)}=22.1, p<0.001\right.$; followed by Bonferroni post hoc tests). Thus, the expression of $\mathrm{C} / \mathrm{EBP} \delta$ in amygdala is significantly induced between 6 and $9 \mathrm{~h}$ after training, remains significantly elevated at $20 \mathrm{~h}$ after training, and returns to baseline by $48 \mathrm{~h}$ after training.

We next asked whether the induction of C/EBP $\delta$ in the BLA was required for the consolidation of IA memory. We first tested the specificity of the antisense $\delta$-ODN injections for the knockdown of $\mathrm{C} / \mathrm{EBP} \delta$ expression levels in the BLA. The diffusion of ODN injections targeting the amygdala have been previously determined and shown to be largely confined to the amygdala, with the highest concentration in the BLA (Milekic et al., 2007). Rats were trained in IA and, $12 \mathrm{~h}$ after training, received a bilateral injection of SC-ODN or $\delta$-ODN into the BLA and were killed $20 \mathrm{~h}$ after training. Quantitative Western blot analyses of lysates obtained from BLA tissue punches showed that $\delta$-ODN significantly decreased $\mathrm{C} / \mathrm{EBP} \delta$ expression levels by $46 \%$ (SC-ODN, $100 \pm 14.5 \% ; \delta$-ODN, $54 \pm 10.7 \%, n=4$ or 5/group; $p<0.05$, Student's $t$ test). This decrease was specific for $\mathrm{C} / \mathrm{EBP} \delta$, as $\mathrm{C} / \mathrm{EBP} \beta$ levels remained unchanged in the same extracts (SCODN, $100 \pm 9.5 ; \delta$-ODN, $100 \pm 14.9$ ). We therefore tested the effect of a bilateral $\delta$-ODN injection into the BLA on memory retention. Groups of rats were trained in IA and, 5 or $12 \mathrm{~h}$ after training, injected with SC-ODN or $\delta$-ODN, and tested $48 \mathrm{~h}$ after training. We chose these two injection time points to block $\mathrm{C} / \mathrm{EBP} \delta$ expression in the BLA starting either before the induction or at a time point when the induction was already in progress. As shown in Figure $3 C, \delta$-ODN injection at either 5 or $12 \mathrm{~h}$ after IA training profoundly disrupted memory retention compared with SC-ODN ( 5 h: $\delta$-ODN, $78.8 \pm 38.8$ s; SC-ODN, $395.3 \pm 56.5 \mathrm{~s}, p<0.001$, Student's $t$ test; $12 \mathrm{~h}: \delta$-ODN, $44.7 \pm$ $11.4 \mathrm{~s}$; SC-ODN, $300.4 \pm 64.9 \mathrm{~s}, p<0.05$, Student's $t$ test). To determine the effect of $\delta$-ODN injections at a time point at which there was no induction of $\mathrm{C} / \mathrm{EBP} \delta$, we delivered $\delta$-ODN or SC$\mathrm{ODN}$ at $48 \mathrm{~h}$ after IA training and tested the retentions $2 \mathrm{~d}$ later. No effect was found (SC-ODN, $310.2 \pm 53.7 \mathrm{~s} ; \delta$-ODN, $324.9 \pm$ $61.8 \mathrm{~s}$; Fig. $3 C$ ). Furthermore, $\delta$-ODN injection into BLA at $12 \mathrm{~h}$ after training did not significantly change the locomotor activity measured by total number of squares crossed (SC-ODN, $193.2 \pm$ $6.3 ; \delta$-ODN, $176.1 \pm 16.7$ ), or the anxiety-like behavior measured by entries into the center zone (SC-ODN, $26.1 \pm 3.0$; $\delta$-ODN, $24.8 \pm 4.0$ ) and time spent in the center zone (SC-ODN, $32.2 \pm 3.5 \mathrm{~s} ; \delta$-ODN, $30.7 \pm 2.4 \mathrm{~s}$ ) in an open field test at $48 \mathrm{~h}$ after training (Fig. 3D).

Together, these data show that, in addition to playing a role in IA memory consolidation in the hippocampus, $\mathrm{C} / \mathrm{EBP} \delta$ is also essential for IA memory consolidation in the amygdala.

Our previous results have shown that protein synthesis and $\mathrm{C} / \mathrm{EBP} \beta$ induction are required in BLA, but not in dorsal hippocampus, for the reconsolidation of IA memory (Taubenfeld et al., 2001a; Tronel et al., 2005; Milekic et al., 2007). Specifically, we have found that injection of antisense targeting C/EBP $\beta 5 \mathrm{~h}$, but not immediately after memory reactivation given $2 \mathrm{~d}$ after training, impaired subsequent IA memory retention. Here, we asked whether $\mathrm{C} / \mathrm{EBP} \delta$, like $\mathrm{C} / \mathrm{EBP} \beta$, plays a role in IA memory reconsolidation. As depicted in Figure $3 E, \delta$-ODN injections into BLA $5 \mathrm{~h}$ after memory reactivation given $2 \mathrm{~d}$ after training (Test 1 ) disrupted memory retention at the subsequent, $96 \mathrm{~h}$ after training, test (Test 2, $89.4 \pm 19.0 \mathrm{~s}, p<0.05$ ), compared with SCODN injections (319.6 $\pm 70.9 \mathrm{~s})$. The effect was contingent upon reactivation, as rats that were injected with $\delta$-ODN $53 \mathrm{~h}$ after training in the absence of Test 1 showed intact memory (283.6 \pm $50.0 \mathrm{~s}$ ). Indeed, no significant difference was found in memory retention of the SC-ODN-injected group and the nonreactivated, $\delta$-ODN-injected group (one-way ANOVA, $F_{(2,23)}=5.96, p=$ 0.009 ; followed by Bonferroni's post hoc test), suggesting that the memory disruption caused by $\delta$-ODN was specific to reactivated memories and not the result of nonspecific effects (Fig. 3E). Hence, $\mathrm{C} / \mathrm{EBP} \delta$ induction in BLA is required for IA memory reconsolidation.

\section{$\mathrm{C} / \mathrm{EBP} \delta$ protein is localized to nuclear, somatic, and dendritic compartments}

The immunocytochemistry findings suggested that $\mathrm{C} / \mathrm{EBP} \delta$ is localized not only in the nucleus but also in the cytoplasm, and, interestingly, in dendrites. To investigate protein localization of $\mathrm{C} / \mathrm{EBP} \delta$ in more detail, we performed fluorescent immunostaining of both HNCs and brain sections of rats trained in IA and killed $20 \mathrm{~h}$ after training. As shown in Figure 4, C/EBP $\delta$ is present in both the soma and dendritic compartments in several brain regions, including the hippocampus (Fig. $4 A a-A d$ ), BLA (Fig. $4 A e-A h)$, cerebellum (Fig. $4 A i-A l$ ), cortex (Fig. $4 A m-A p)$, and HNCs (Fig. $4 B a-B c$ ). C/EBP $\delta$ immunostaining was confirmed to be specific for $\mathrm{C} / \mathrm{EBP} \delta$, as preincubation of the $\mathrm{C} / \mathrm{EBP} \delta$ antibody with an excess of $\delta$-MBP completely and specifically competed the immunofluorescence (Fig. $4 B d-B f$ ), whereas an excess of control MBP had no effect (Fig. $4 B g-B i$ ). No change was observed with the dendritic marker anti-MAP2 staining in noncompeted, $\delta$-MBP or control MBP conditions (Fig. $4 B b, B e, B h$ ).

\section{$\mathrm{C} / \mathrm{EBP} \delta \mathrm{mRNA}$ is localized to dendritic compartments in HNCs}

Several dendritically localized proteins have been reported to also have their mRNA localized to dendrites (Wu et al., 2007), and dendritic translation has been suggested to play an important role 


\section{AMYGDALA}

A

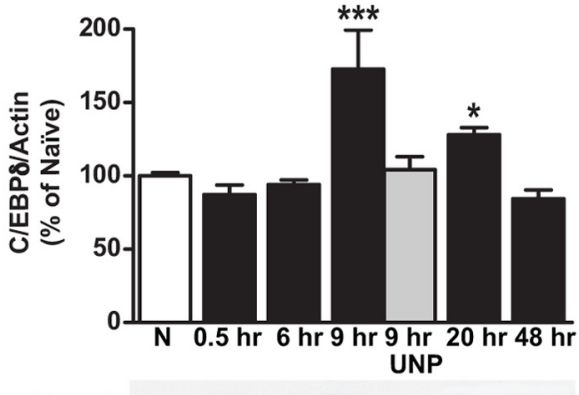

B
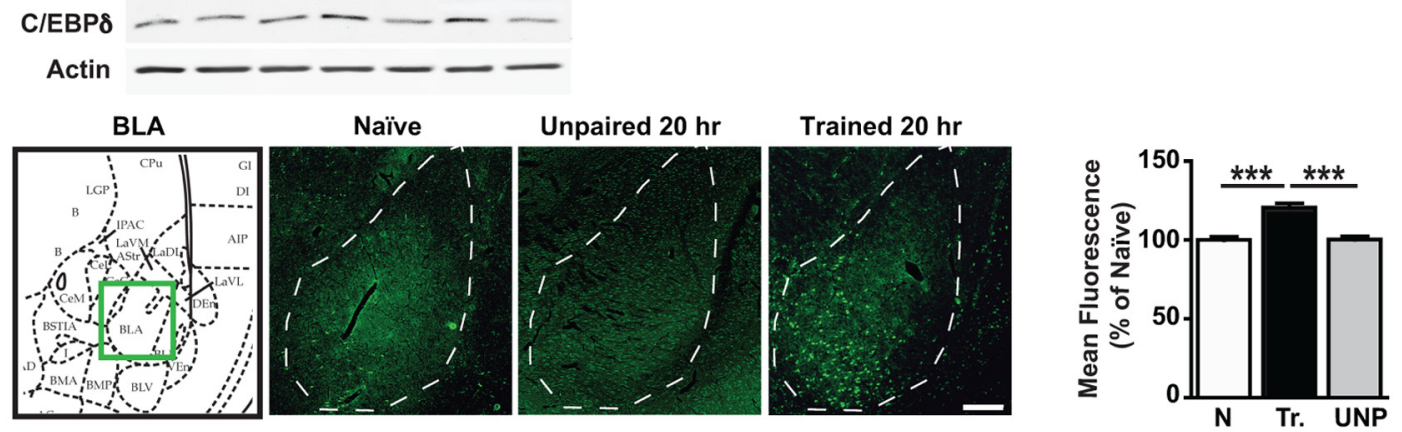

C
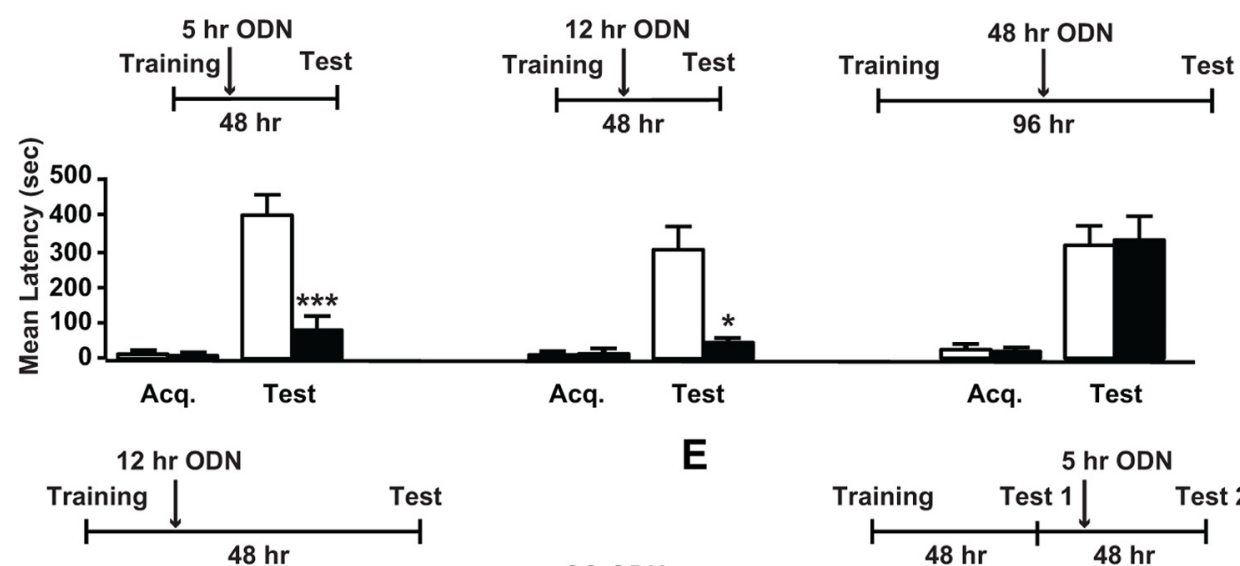

\section{est}

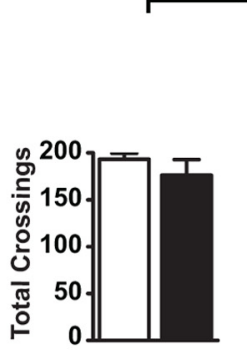

Locomotor

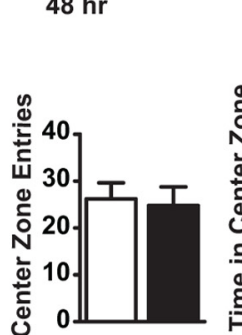

Anxiety

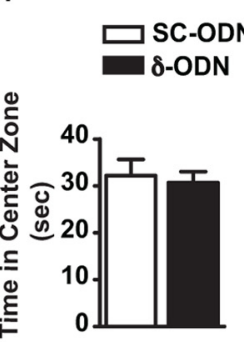

8-ODN

Figure 3. C/EBP $\delta$ in the BLA is upregulated after training and required for the consolidation and reconsolidation of IA memory. $A$, Quantitative Western blot analysis of C/EBP $\delta$ in BLA extracts with representative blots shown below each graph. C/EBP $\delta$ levels were significantly increased at 9 and $20 \mathrm{~h}$ after training compared with naive controls: ${ }^{*} p<0.05 ; * * * p<$ 0.001. No significant change was found at $0.5,6$, or $48 \mathrm{~h}$ after training (naive, $n=22 ; 0.5 \mathrm{~h}, n=10 ; 6 \mathrm{~h}, n=7 ; 9 \mathrm{~h}, n=7 ; 20 \mathrm{~h}, n=13 ; 48 \mathrm{~h}, n=11$ ). (/EBP $\delta$ level at $9 \mathrm{~h}$ after unpaired protocol was not different from that of naive conditions but significantly different from the trained $(n=6)$. Data are expressed as mean percentage \pm SEM of naive (100\%) control mean values. $\boldsymbol{B}$, Representative examples of C/EBP $\delta$ immunohistochemical staining in the BLA of naive, unpaired, or IA trained rats. Scale bar, $200 \mu \mathrm{m}$. Quantitative analyses of C/EBP $\delta$ fluorescence intensity showed a significant increase of C/EBP $\delta$ levels in the BLA of rats $20 \mathrm{~h}$ after training compared with naive and unpaired controls killed at the matched time point $\left(n=4 /\right.$ group ): ${ }^{* * *} p<0.001$. C, Rats were injected with SC-0DN or $\delta$-0DN 5 or $12 \mathrm{~h}$ after training and were tested $48 \mathrm{~h}$ after training. In both cases, $\delta$-0DN profoundly disrupted memory retention compared with SC-ODN (SC-ODN, $n=7-9 ; \delta-0 D N, n=6$ or 7$):{ }^{* * *} p<0.0001 ;{ }^{*} p<0.05$. In contrast, SC-ODN or $\delta$-0DN injections 48 h after training did not affect memory tested $96 \mathrm{~h}$ after training (SC-ODN, $n=9 ; \delta$-ODN, $n=10$ ). Retentions are expressed as mean latency \pm SEM in seconds. D, Rats injected with $\delta$-ODN $12 \mathrm{~h}$ after training showed no difference in locomotor activity and anxiety-like activity, measured by entries into and time spent in the center zone, compared with SC-0DN-injected rats in the open field test at $48 \mathrm{~h}$ after training ( $n=8-10 /$ group). $\boldsymbol{E}$, Rats injected with $\delta$-ODN $5 \mathrm{~h}$ after memory reactivation (Test $1, \mathrm{R}, \delta-0 \mathrm{DN}, n=8$ ) showed significantly lower latencies when retested $48 \mathrm{~h}$ later, compared with rats injected with $\mathrm{SC}-0 \mathrm{DN}(\mathrm{R}, \mathrm{SC}-0 \mathrm{DN}, n=8)$ or rats injected with $\delta-0 \mathrm{DN}$ at the matching time point in the absence of memory reactivation (NR, $\delta$-0DN, $n=7)$. 
A
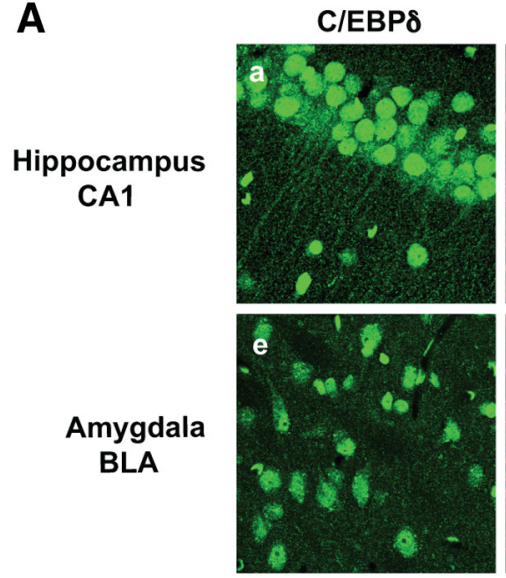

Cerebellum
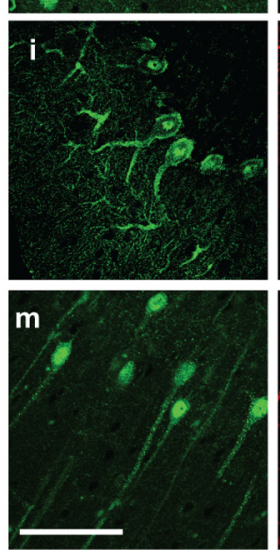

B

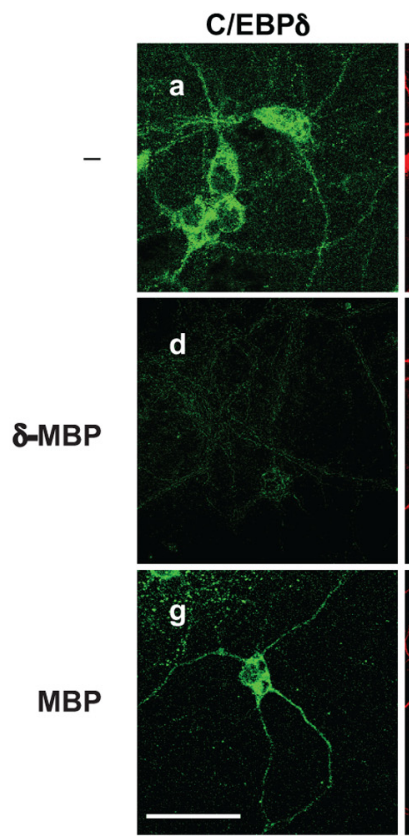

MAP2
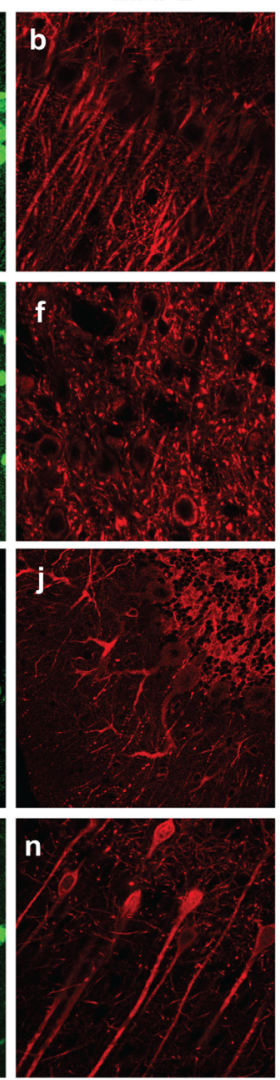

MAP2
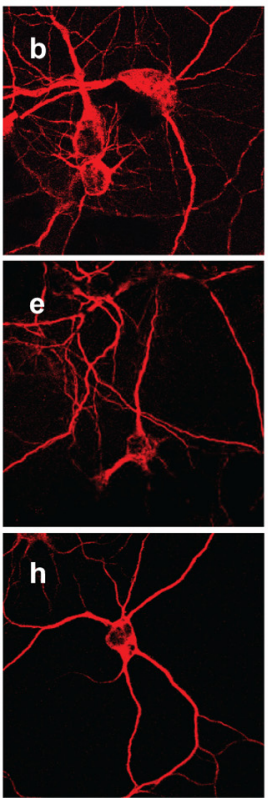

MERGE
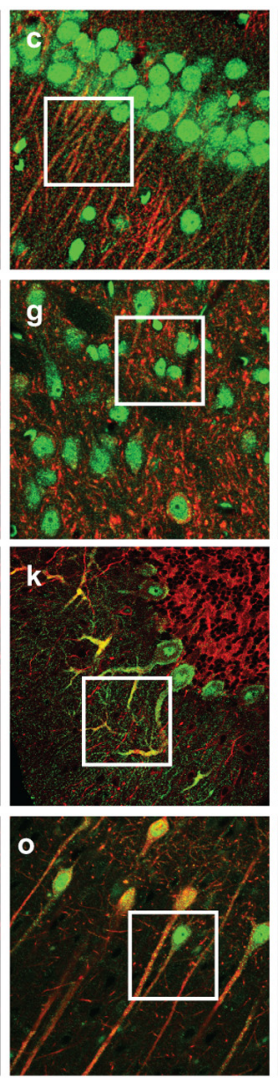

MERGE
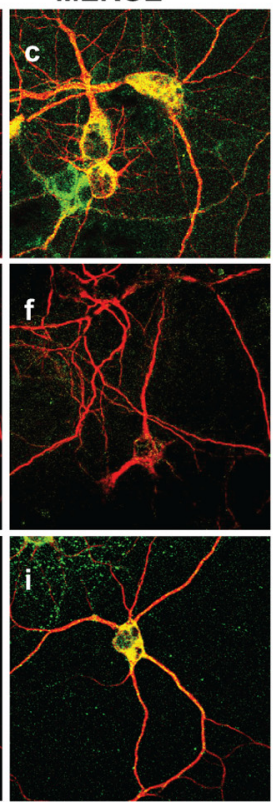

Figure 4. C/EBP $\delta$ immunofluorescent staining. $A$, Representative immunofluorescence of C/EBP $\delta$ (green) and the dendritic marker MAP2 (red) on brain sections taken $20 \mathrm{~h}$ after training. $\boldsymbol{a}-\boldsymbol{c}$, Hippocampus. e- $\boldsymbol{g}$, Amygdala, $\boldsymbol{i}-\boldsymbol{k}$, Cerebellum. $\boldsymbol{m}-\boldsymbol{0}$, Cortex. Scale bar, $50 \mu \mathrm{m} . \boldsymbol{C}, \boldsymbol{g}, \boldsymbol{k}, \boldsymbol{0}$, Boxed regions are shown at high magnification of $\boldsymbol{d}, \boldsymbol{h}, \boldsymbol{I}$, and $\boldsymbol{p}$, respectively. Scale bar, $15 \mu \mathrm{m}$. $\boldsymbol{B}$, Representative immunofluorescence of C/EBP $\delta$ and MAP2 on hippocampal neuronal cultures, and validation of C/EBP $\delta$ antibody specificity for immunofluorescent staining. $\boldsymbol{a}-\boldsymbol{c},-$, no competition. C/EBP $\delta$ immunofluorescence (green) detected by anti-C/EBP $\delta$ is evident in the somatic and dendritic (MAP2-positive, red) compartments. $\boldsymbol{d}-\boldsymbol{f}$, Twenty $\times$ excess of $\delta$-MBP incubated with anti-C/EBP $\delta$ competed for C/EBP $\delta$ (green) but not for MAP2 (red) immunofluorescence. $\boldsymbol{g}-\boldsymbol{i}$, Twenty times excess of MBP (control) did not compete for C/EBP $\delta$ (green) or MAP2 (red) immunofluorescence. Scale bar, $25 \mu \mathrm{m}$.

in local regulation of synaptic plasticity (Martin and Zukin, 2006; Richter and Klann, 2009). To determine whether dendritic localization of $\mathrm{C} / \mathrm{EBP} \delta$ might be a result of local translation, we performed FISH with sense or antisense riboprobes in both brain sections and HNCs. As shown in Figure 5, in hippocampal sections, $\mathrm{C} / \mathrm{EBP} \delta$ immunofluorescence with $\mathrm{C} / \mathrm{EBP} \delta$ antisense riboprobe was detected mainly in the cell body but very sparsely also in dendritic compartments (Fig. 5Ab), and, as expected, no signal 
A C/EBPS SENSE
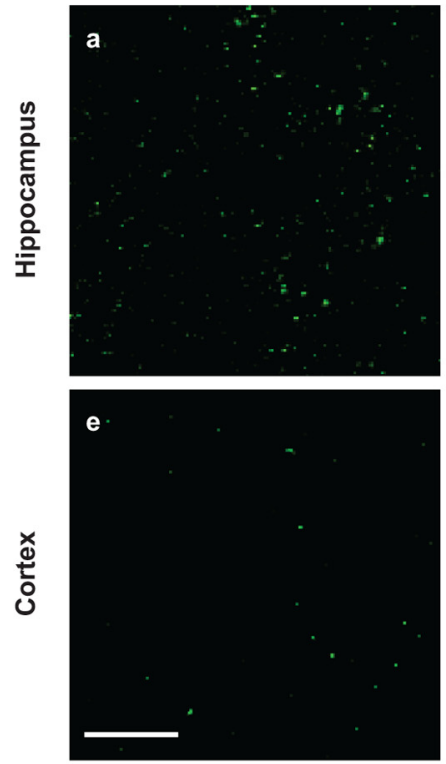

B

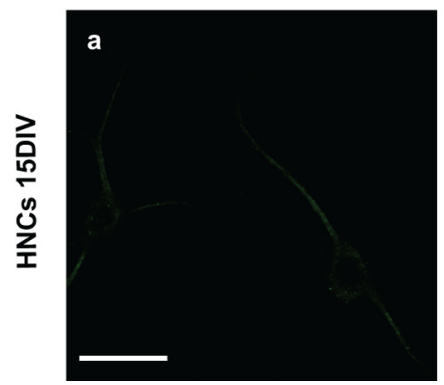

C/EBP $\delta$ anti-SENSE
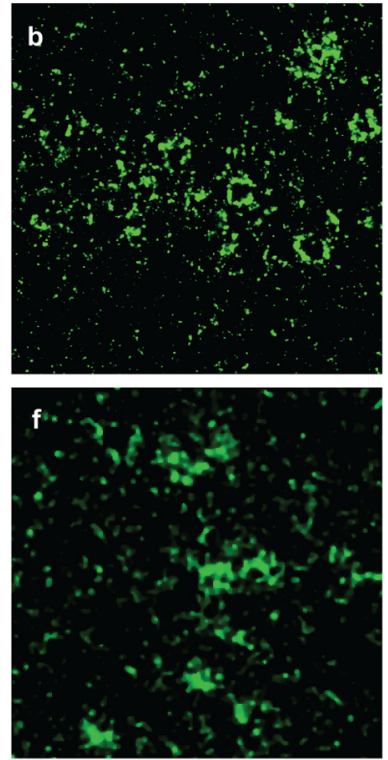

C/EBPS anti-SENSE

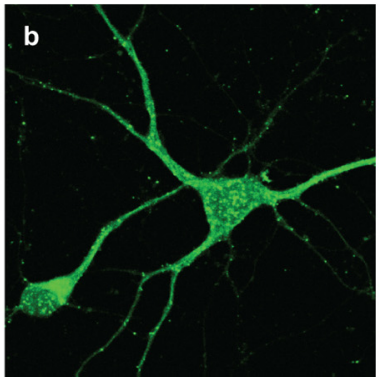

MAP2
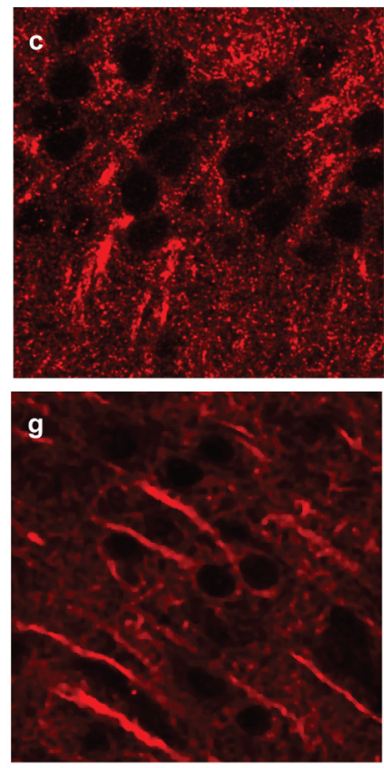

MAP2

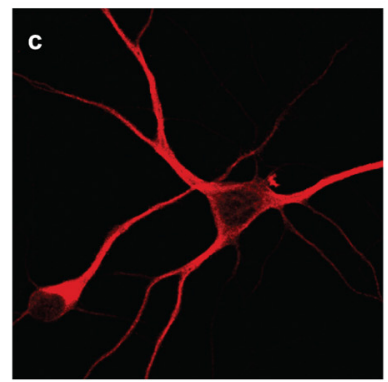

MERGE
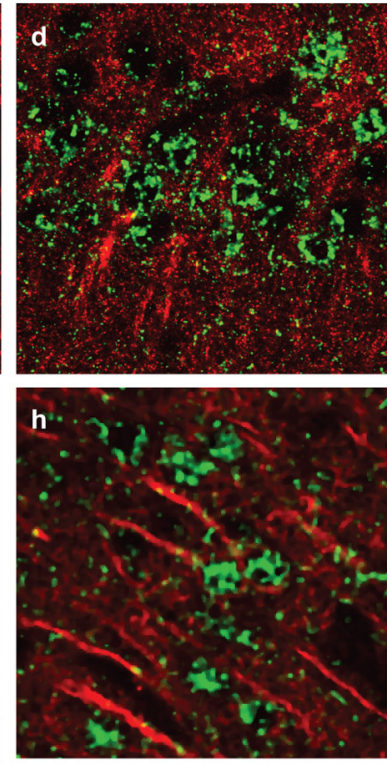

MERGE

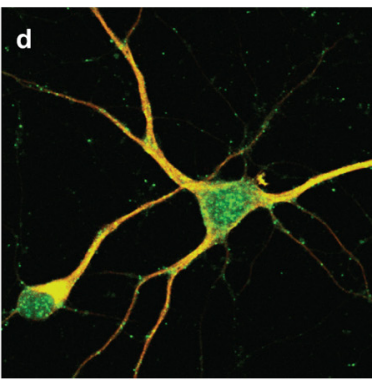

Figure 5. C/EBP $\delta$ FISH. A, Hippocampal CA1 (a- $\boldsymbol{d})$ and insular cortical sections $(\boldsymbol{e}-\boldsymbol{h})$ taken $20 \mathrm{~h}$ after training were hybridized with control C/EBP $\delta$ sense probe $(\boldsymbol{a}, \boldsymbol{e})$ or $\mathrm{C} / \mathrm{EBP} \delta$ antisense probe $(\boldsymbol{b}, \boldsymbol{f})$. Dendritic regions of brain sections shown in $\boldsymbol{b}$ and $\boldsymbol{f}$ are revealed by MAP2 immunostaining $(\boldsymbol{c}, \boldsymbol{g})$. Merged images of (/EBP $\delta$ mRNA (green) and MAP2 (red) show primary somatic localization of C/EBP $\delta$ mRNA in adult rat brain sections. Scale bar, $25 \mu \mathrm{m}$. B, C/EBP $\delta$ FISH of hippocampal neuronal cultures. $\boldsymbol{a}$, Control C/EBP $\delta$ sense probe. $\boldsymbol{b}$, Antisense probe to C/EBP $\delta . \boldsymbol{c}$, MAP2 immunofluorescence. $\boldsymbol{d}$, Merged image of C/EBP $\delta$ mRNA (green) and MAP2 (red) reveals the localization of C/EBP $\delta$ mRNA in both somatic and dendritic compartments of cultured hippocampal neurons. Scale bar, $12.5 \mu \mathrm{m}$.

was observed with control sense riboprobe (Fig. 5Aa). In contrast, HNCs showed a clearly detectable signal with $\mathrm{C} / \mathrm{EBP} \delta$ antisense riboprobe (Fig. $5 B b$ ) in both the somatic and dendritic compartments compared with control sense riboprobe (Fig. $5 B a$ ), suggesting that $\mathrm{C} / \mathrm{EBP} \delta$ protein may be translated in dendrites (Fig. $5 B b, B c$ ).

\section{$\mathrm{C} / \mathrm{EBP} \delta$ protein is increased in the nucleus after LTP}

IA training induces an LTP-like synaptic plasticity in area CA1, which is thought to be a cellular model of long-term memory (Whitlock et al., 2006). Previous studies have shown that stimuli that elicit LTP or other types of synaptic plasticity can induce retrograde translocation of importins or transcription factors that are present in dendrites, including CREB2, CREB-regulated transcriptional coactivator 1 , importin $\alpha$, NF- $\kappa \mathrm{B}$, and Elk-1 (Meffert et al., 2003; Thompson et al., 2004; Lavaur et al., 2007; Lai et al., 2008; Jeffrey et al., 2009; Ch'ng et al., 2012). Therefore, we asked whether a change in the subcellular distribution of $\mathrm{C} / \mathrm{EBP} \delta$ occurs after hippocampal LTP. We induced long-lasting LTP at CA3-CA1 synapses using high-frequency stimulation (Bozdagi et al., 2000). At either 15 or 45 min after stimulation, $350-\mu \mathrm{m}$-thick hippocampal slices were either snap-frozen for quantitative Western blot analyses or postfixed and sectioned at
$30 \mu \mathrm{m}$ for immunohistochemical staining. Quantitative Western blot analyses of cytoplasmic and nuclear fractions of control or LTP-induced hippocampal slices were performed. The fractionation was validated with the nuclear and cytoplasmic markers NPC and $\beta$-tubulin, respectively. NPC protein was indeed enriched in the nuclear compared with the cytoplasmic fraction, whereas $\beta$-tubulin was enriched in the cytoplasmic fraction (Fig. $6 A)$. Levels of cytoplasmic $\mathrm{C} / \mathrm{EBP} \delta$ were normalized to $\beta$-tubulin and nuclear C/EBP $\delta$ to NPC (Fig. $6 A$ ). At 15 min after LTP induction, we observed no significant change in protein levels or subcellular redistribution in $\mathrm{C} / \mathrm{EBP} \delta$ in either the cytoplasmic or nuclear compartments (Fig. 6B). However, $45 \mathrm{~min}$ after LTP induction, although no change in $\mathrm{C} / \mathrm{EBP} \delta$ in the cytoplasmic fraction was found, there was a significant increase in the nuclear fraction $(361 \pm 116.9 \%)$ compared with the nuclear fraction of unstimulated controls ( $100 \pm 54.4 \%, p<0.05$, Student's $t$ test; Fig. 6C). Hence, after LTP there is an induction and nuclear redistribution of $\mathrm{C} / \mathrm{EBP} \delta$ protein.

The pattern of immunofluorescent localization of C/EBP $\delta$ in CA1 was consistent with the Western blot analyses. As shown in Figure $6 D$, at $15 \mathrm{~min}$ after LTP induction, there was no difference in the intensity of $\mathrm{C} / \mathrm{EBP} \delta$ immunofluorescence between the control and stimulated sections (Fig. 6Da,Dc). However, at 45 
A

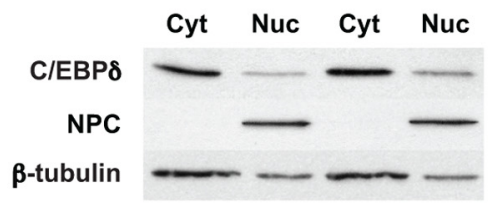

B

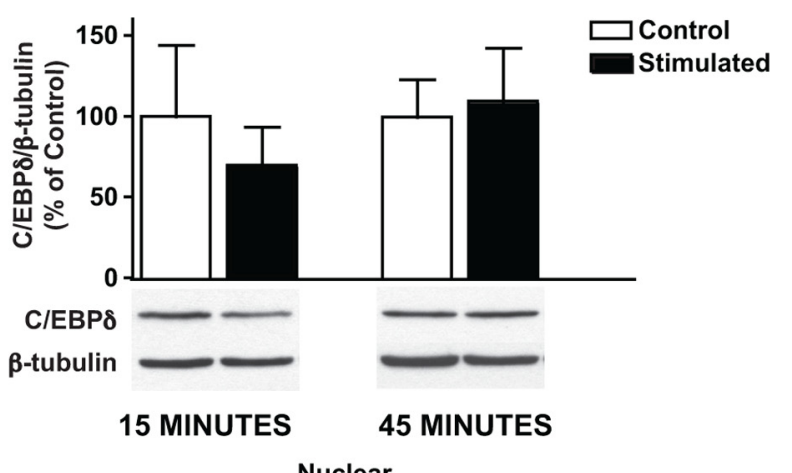

C

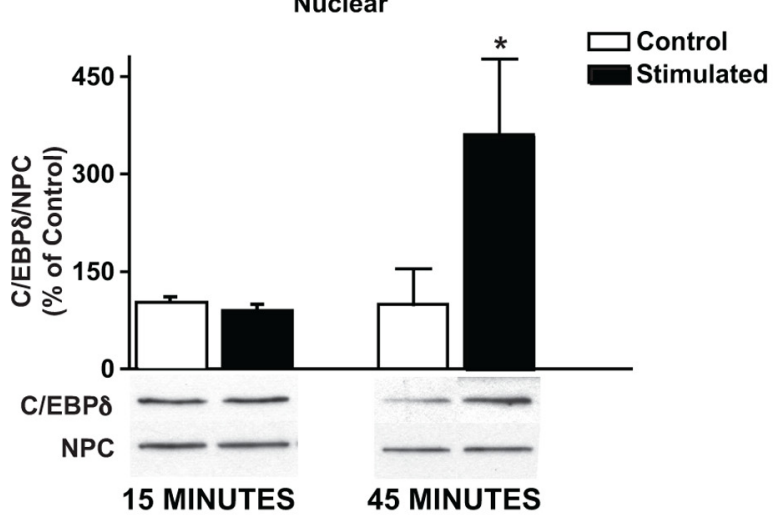

D
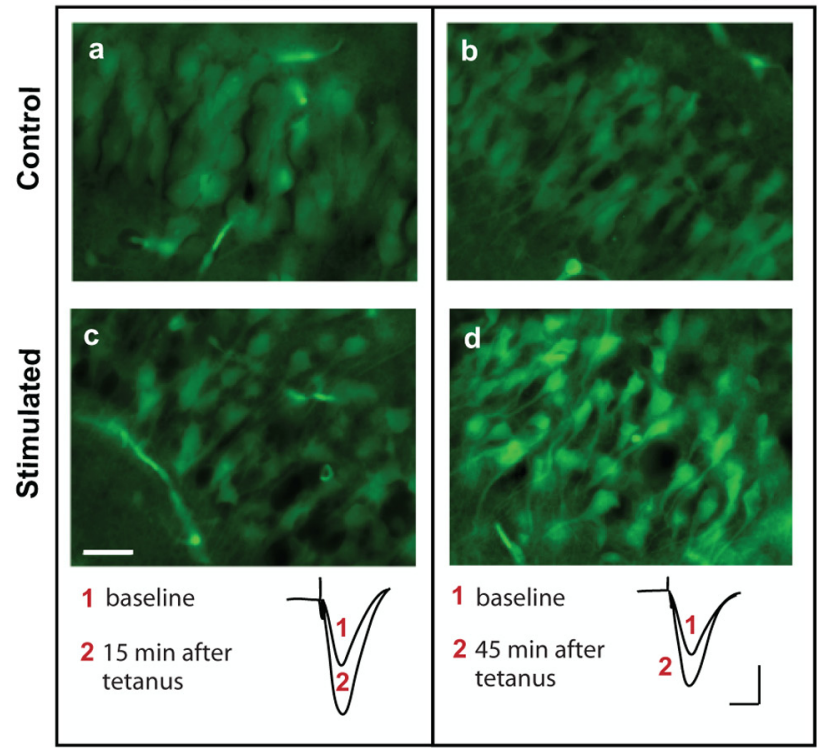

Figure 6. C/EBP $\delta$ expression is induced after LTP. $\boldsymbol{A}$, Representative Western blots validating cytoplasmic (Cyt) and nuclear (Nuc) fractionation of C/EBP $\delta$ expression levels. NPC, immunostaining with anti-NPC is enriched in the nuclear fraction; $\beta$-tubulin, immunostaining with anti- $\beta$-tubulin is enriched in the cytoplasmic fraction. $\boldsymbol{B}$, Quantitative Western blot analyses of cytoplasmic fractions from hippocampal slices processed 15 min or 45 after LTP induction; C/EBP $\delta$ protein levels remain unchanged. Representative Western blot examples are shown below each graph. Data are expressed as mean percentage \pm SEM of unstimulated slice extract (control) mean values ( $n=4$ /group). C, Quantitative Western blot analyses of nuclear fractions min after LTP a clear increase in the intensity of C/EBP $\delta$ immunofluorescence, which also appears to be localized in the nuclei, was observed (Fig. 6Db,Dd).

\section{Discussion}

The CREB-C/EBP is a highly evolutionarily conserved gene expression pathway engaged in long-term memory formation and enduring synaptic plasticity (Alberini, 2009). For example, in Aplysia californica, serotonin-driven induction of ApC/EBP in sensory neurons follows that of CREB phosphorylation, and its function is required for long-term facilitation (Alberini et al., 1994; Bartsch et al., 1995). On the other hand, overexpression of ApC/EBP promotes the induction of long-term facilitation from a protocol that only elicits short-term facilitation (Lee et al., 2001). In rat hippocampus, we have reported that IA training leads to CREB phosphorylation at Ser133 immediately after training, followed $9 \mathrm{~h}$ later by an induction in the expression of $\mathrm{C} / \mathrm{EBP} \beta$ in the same neuronal populations (Taubenfeld et al., 2001b). Antisense-mediated knockdown of the learningdependent $\mathrm{C} / \mathrm{EBP} \beta$ induction in the hippocampus prevents long-term memory formation during a limited temporal window, which starts $5 \mathrm{~h}$ after training and ends by $2 \mathrm{~d}$ after training, paralleling the kinetics of C/EBP $\beta$ induction (Taubenfeld et al., $2001 \mathrm{a}$; b). This hippocampal requirement of $\mathrm{C} / \mathrm{EBP} \beta$ induction is specific for the consolidation of a new IA memory but not for the reconsolidation of a reactivated IA memory (Taubenfeld et al., 2001a). In contrast, $\mathrm{C} / \mathrm{EBP} \beta$ induction in the amygdala is required for the reconsolidation but not consolidation of IA memory (Milekic et al., 2007). Our present results add to this knowledge by showing that another isoform of C/EBP, which is encoded by a distinct gene, $\mathrm{C} / \mathrm{EBP} \delta$, is also critically regulated and required for IA memory consolidation and reconsolidation. Notably, the hippocampal induction of C/EBP $\delta$ is observed several hours after training, and specifically between 12 and $20 \mathrm{~h}$. Correspondingly, $\delta$-ODN injection into the hippocampus just before the $\mathrm{C} / \mathrm{EBP} \delta$ induction, at $12 \mathrm{~h}$, but not at $5 \mathrm{~h}$ after training impairs IA memory. Moreover, $\mathrm{C} / \mathrm{EBP} \delta$ expression is increased in the amygdala starting between 6 and $9 \mathrm{~h}$ after training, and the increase persists for up to $20 \mathrm{~h}$ after training. Similar to its induction in the hippocampus, $\mathrm{C} / \mathrm{EBP} \delta$ induction in the BLA is required for IA memory consolidation. Finally, in line with what was previously found with $\mathrm{C} / \mathrm{EBP} \beta$ (Milekic et al., 2007), C/EBP $\delta$ in the amygdala is also required for IA memory reconsolidation. These data, together with our previous studies on $\mathrm{C} / \mathrm{EBP} \beta$, indicate that both $\mathrm{C} / \mathrm{EBP}$ isoforms are essential in the hippocampus for memory consolidation and in the amygdala for reconsolidation, but in the amygdala only $\mathrm{C} / \mathrm{EBP} \delta$ is required for consolidation. This suggests that region-specific coregulation or differential regulation of transcription occurs via $\mathrm{C} / \mathrm{EBP} \beta$ and $\delta$ after IA training and retrieval. Our data also confirm several previous findings, starting from our results on phosphorylated CREB and C/EBP $\beta$ in IA (Taubenfeld et al., 2001a, b) and then

\section{$\leftarrow$}

from hippocampal slices processed 15 or 45 min after LTP induction; C/EBP $\delta$ levels significantly increase in the nuclear fraction at $45 \mathrm{~min}$ but not at $15 \mathrm{~min}$ after LTP induction. Representative Western blot examples are shown below each graph. Data are expressed as mean percentage \pm SEM of unstimulated slice extract (control) mean values ( $n=4 /$ group). $D$, Examples of anti-C/EBP $\delta$ immunofluorescence staining showing no change in C/EBP $\delta$ levels $15 \mathrm{~min}$ after LTP induction (c) compared with unstimulated control $(\boldsymbol{a})$. C/EBP $\delta$ immunofluorescence increases 45 min after LTP induction (d) compared with unstimulated control (b) ( $n=4 /$ group). Scale bar, $20 \mu \mathrm{m}$. Bottom, Representative traces from LTP-elicited slices. Traces were recorded before and 15 (c) or $45 \mathrm{~min}$ (d) after LTP induction. Calibration: $10 \mathrm{~ms}, 0.5 \mathrm{mV}$. 
also reported with other molecules, including BDNF, MuSK, and IGF-II in different species and systems, indicating that the gene expression-dependent phase underlying memory consolidation lasts for $>24 \mathrm{~h}$. This gene expression recruits a cascade of events, some of which occurring hours after training (late events) are critical for sustaining the consolidation process, a step necessary for the persistence of memory (Garcia-Osta et al., 2006; Beckinschtein et al., 2007; Miniaci et al., 2008; Ou et al., 2010, Chen et al., 2011).

Both temporal and spatial coregulation of $\mathrm{C} / \mathrm{EBP} \beta$ and $\mathrm{C} / \mathrm{EBP} \delta$ has been reported in many cell types (Cardinaux and Magistretti, 1996; Yukawa et al., 1998; Thomas et al., 2000), and both isoforms have been found to be regulated in response to common stimuli, including $\mathrm{Ca}^{2+}$, cAMP, and protein kinase A, which are also known to be critical mediators of synaptic plasticity (Breed et al., 1997; Yukawa et al., 1998; Pohnke et al., 1999). Our present data showing that $\mathrm{C} / \mathrm{EBP} \delta$, like $\mathrm{C} / \mathrm{EBP} \beta$, is required in the hippocampus for IA consolidation, and that learning induces both isoforms in the same neuronal population (Taubenfeld et al., 2001b) suggest that the two isoforms may heterodimerize or exert a concerted action at specific time points.

Although the coinduction of $\mathrm{C} / \mathrm{EBP} \beta$ and $\delta$ may imply a potential heterodimerization at certain time points, it seems clear that in the hippocampus $\mathrm{C} / \mathrm{EBP} \beta$ is induced before $\mathrm{C} / \mathrm{EBP} \delta$; and, in agreement, a sequential functional role in memory consolidation was also revealed by the antisense-mediated knock-down experiments. Whereas hippocampal C/EBP $\beta$ antisense injection at $5 \mathrm{~h}$ after training completely blocks long-term IA retention (Taubenfeld et al., 2001a), similar injections of C/EBP $\delta$ antisense have no effect, and only later, at $12 \mathrm{~h}$ after training, the same treatment significantly disrupts long-term IA retention. Thus, it is unclear whether $\mathrm{C} / \mathrm{EBP} \delta$, at least in the hippocampus, regulates common or different sets of genes than those controlled by $\mathrm{C} / \mathrm{EBP} \beta$, and/or whether the two isoforms heterodimerize at some point in time during memory consolidation. On the other hand, as previous studies from our laboratory have found that $\mathrm{C} / \mathrm{EBP} \beta$ is dispensable in the amygdala during memory consolidation, and here we show that $\mathrm{C} / \mathrm{EBP} \delta$ is required in both consolidation and reconsolidation; we conclude that the two isoforms are not always recruited in parallel. One possible explanation for this differential regional recruitment, which needs to be explored in future studies, is that $\mathrm{C} / \mathrm{EBP} \beta$ and $\mathrm{C} / \mathrm{EBP} \delta$, at least in some neuronal subpopulations, may be functionally redundant. Alternatively, both isoforms may be recruited to regulate different sets of genes. Given the dendritic localization of $\mathrm{C} / \mathrm{EBP} \delta$, its induction may stabilize changes that have already occurred at activated synapses, where it may have been translated or activated for translocation to the nucleus.

Our data are in apparent disagreement with previous studies from Sterneck et al. (1998) who generated mice with a targeted deletion of the C/EBP $\delta$ gene and found that, although they performed normally on several behavioral tasks, they exhibited a selective enhancement in contextual fear conditioning. Although there are potentially several explanations that could account for the different outcomes obtained in the two studies, a most likely one is that Sterneck et al. (1998) used a global deletion in mice that may influence the whole organism throughout development, while we used a spatially and temporally restricted disruption of the learning-induced upregulation of C/EBP $\delta$ in adult rat brains.

Another study that examined the role of C/EBP-related transcription factors in long-term synaptic plasticity and memory storage used a tetracycline-regulated system and expressed in the forebrain of mice a broad dominant-negative inhibitor of C/EBP
(EGFP-AZIP) (Chen et al., 2003). This inhibitor is known to preferentially interact with several inhibitory isoforms of C/EBP but also reduce the expression of activating transcription factor 4 , a member of the CREB-activating transcription factor family of transcription factors. The expression of the dominant negative inhibitor resulted in enhanced hippocampal spatial memory and LTP, leading the authors to speculate on a possible inhibitory role of C/EBPs or CREB isoforms. Our results are not in disagreement with this study as, indeed, multiple C/EBP and CREB isoforms exist, and some of them can act as inhibitory constraints (Alberini, 2009).

Interestingly, we found that the expression of $\mathrm{C} / \mathrm{EBP} \delta$ protein is localized to nuclear, somatic, and dendritic compartments in the neurons of multiple brain regions and cultured hippocampal neurons. Furthermore, C/EBP $\delta$ mRNA is present in both the soma and dendrites of neuronal cultures, whereas it appears to be primarily detected in the neuronal soma in the brain of adult rats. The reasons for the different degree of C/EBP $\delta$ mRNA dendritic localization between hippocampal neuronal cultures and adult brain remain to be determined. Several explanations may be considered, including the age of the cells, in vitro versus in vivo conditions, different levels of neural activity, or simply differential concentrations and localizations in microdomains.

The dendritic localization of C/EBP $\delta$ protein, and in some conditions its mRNA, may have an important role in relaying signals between the synapse and the nucleus. The dendritic distribution suggests that, at least in certain conditions, $\mathrm{C} / \mathrm{EBP} \delta$ mRNA may be translated locally. Interestingly, C/EBP $\delta$ mRNA carries the cytoplasmic polyadenylation element consensus UUUUUAU that may in principle regulate its translation, similarly to $\alpha$ CaMKII (Wu et al., 1998). Furthermore, Suzuki et al. (2007) reported that $\mathrm{C} / \mathrm{EBP} \delta$ mRNA is present in postsynaptic densities of rat forebrain, suggesting that, although not detectable in vivo in dendrites, $\mathrm{C} / \mathrm{EBP} \delta$ mRNA may be present in low concentrations and localized in the proximity of postsynaptic densities. Interestingly, our in situ $\mathrm{C} / \mathrm{EBP} \delta$ hybridizations of brain sections showed puncta that may indeed represent dendritically localized mRNA.

We speculate that local, dendritic changes may regulate the distribution of $\mathrm{C} / \mathrm{EBP} \delta$ and perhaps its translocation to the nucleus, as also suggested by its nuclear accumulation found after LTP induction. Relevant to this hypothesis is the finding by Lai et al. (2008) who showed that CREB2/activating transcription factor 4, a transcriptional repressor that modulates long-term synaptic plasticity and memory, localizes to distal dendrites of rodent hippocampal neurons and neurites of Aplysia sensory neurons, binds to specific importin $\alpha$ isoforms, and is transported from distal dendrites into the nucleus following the induction of long-term depression. In addition, a recent study by Ch'ng et al. (2012) has found that CREB-regulated transcriptional coactivator 1 is localized in dendritic spines and translocates specifically from the stimulated synapses into the nucleus in response to synaptic activity and LTP induction stimuli. Further experiments should be able to clearly address whether dendritic $\mathrm{C} / \mathrm{EBP} \delta$ translocates into the nucleus in an activity-dependent manner. Notably, although LTP is a cellular model of the mechanisms underlying memory formation, the temporal dynamics of molecular signaling and regulation events underlying LTP and memory formation can be very different. Our data suggest that both LTP and IA training induce C/EBP $\delta$ expression, but the time courses of the induction are different, which is not surprising considering the diversity of learning from tetanic stimulation on a slice. 
In conclusion, our study reveals important roles of $\mathrm{C} / \mathrm{EBP} \delta$ in the hippocampus and the amygdala for memory consolidation and in the amygdala for reconsolidation. Our results suggest that $\mathrm{C} / \mathrm{EBP} \delta$ may act both in concert and in series with $\mathrm{C} / \mathrm{EBP} \beta$, resulting in complex temporal and regional control of gene transcription critical for long-term memory formation. Finally, our findings of dendritic localization of C/EBP $\delta$ and its nuclear accumulation after LTP induction indicate that it may convey specific synaptic changes to the nucleus.

\section{References}

Alberini CM (2008) The role of protein synthesis during the labile phases of memory: revisiting the skepticism. Neurobiol Learn Mem 89:234-246. CrossRef Medline

Alberini CM (2009) Transcription factors in long-term memory and synaptic plasticity. Physiol Rev 89:121-145. CrossRef Medline

Alberini CM (2011) The role of reconsolidation and the dynamic process of long-term memory formation and storage. Front Behav Neurosci 5:12. CrossRef Medline

Alberini CM, Ghirardi M, Metz R, Kandel ER (1994) C/EBP is an immediate-early gene required for the consolidation of long-term facilitation in Aplysia. Cell 76:1099-1114. CrossRef Medline

Alberini CM, Ghirardi M, Huang YY, Nguyen PV, Kandel ER (1995) A molecular switch for the consolidation of long-term memory: cAMPinducible gene expression. Ann N Y Acad Sci 758:261-286. CrossRef Medline

Athos J, Impey S, Pineda VV, Chen X, Storm DR (2002) Hippocampal CREmediated gene expression is required for contextual memory formation. Nat Neurosci 5:1119-1120. CrossRef Medline

Bartsch D, Ghirardi M, Skehel PA, Karl KA, Herder SP, Chen M, Bailey CH, Kandel ER (1995) Aplysia CREB2 represses long-term facilitation: relief of repression converts transient facilitation into long-term functional and structural change. Cell 83:979-992. CrossRef Medline

Bekinschtein P, Cammarota M, Igaz LM, Bevilaqua LR, Izquierdo I, Medina JH (2007) Persistence of long-term memory storage requires a late protein synthesis- and BDNF-dependent phase in the hippocampus. Neuron 53:261-277. CrossRef Medline

Bozdagi O, Shan W, Tanaka H, Benson DL, Huntley GW (2000) Increasing numbers of synaptic puncta during late-phase LTP: N-cadherin is synthesized, recruited to synaptic sites, and required for potentiation. Neuron 28:245-259. CrossRef Medline

Breed DR, Margraf LR, Alcorn JL, Mendelson CR (1997) Transcription factor C/EBP $\delta$ in fetal lung: developmental regulation and effects of cyclic adenosine $3^{\prime}, 5^{\prime}$-monophosphate and glucocorticoids. Endocrinology 138:5527-5534. CrossRef Medline

Cao Z, Umek RM, McKnight SL (1991) Regulated expression of three C/EBP isoforms during adipose conversion of 3T3-L1 cells. Genes Dev 5:1538-1552. CrossRef Medline

Cardinaux JR, Magistretti PJ (1996) Vasoactive intestinal peptide, pituitary adenylate cyclase-activating peptide, and noradrenaline induce the transcription factors CCAAT/enhancer binding protein (C/EBP)- $\beta$ and C/EBP $\delta$ in mouse cortical astrocytes: involvement in cAMP-regulated glycogen metabolism. J Neurosci 16:919-929. Medline

Chen A, Muzzio IA, Malleret G, Bartsch D, Verbitsky M, Pavlidis P, Yonan AL, Vronskaya S, Grody MB, Cepeda I, Gilliam TC, Kandel ER (2003) Inducible enhancement of memory storage and synaptic plasticity in transgenic mice expressing an inhibitor of ATF4 (CREB-2) and C/EBP proteins. Neuron 39:655-669. CrossRef Medline

Chen DY, Stern SA, Garcia-Osta A, Saunier-Rebori B, Pollonini G, BambahMukku D, Blitzer RD, Alberini CM (2011) A critical role for IGF-II in memory consolidation and enhancement. Nature 469:491-497. CrossRef Medline

Chen DY, Bambah-Mukku D, Pollonini G, Alberini CM (2012) Glucocorticoid receptors recruit the CaMKII $\alpha$-BDNF-CREB pathways to mediate memory consolidation. Nat Neurosci 15:1707-1714. CrossRef Medline

Ch'ng TH, Uzgil B, Lin P, Avliyakulov NK, O’Dell TJ, Martin KC (2012) Activity-dependent transport of the transcriptional coactivator CRTC1 from synapse to nucleus. Cell 150:207-221. CrossRef Medline

Davis HP, Squire LR (1984) Protein synthesis and memory: a review. Psychol Bull 96:518-559. CrossRef Medline
Dudai Y (2004) The neurobiology of consolidations, or, how stable is the engram? Annu Rev Psychol 55:51-86. CrossRef Medline

Dudai Y, Eisenberg M (2004) Rites of passage of the engram: reconsolidation and the lingering consolidation hypothesis. Neuron 44:93-100. CrossRef Medline

Garcia-Osta A, Tsokas P, Pollonini G, Landau EM, Blitzer R, Alberini CM (2006) MuSK expressed in the brain mediates cholinergic responses, synaptic plasticity, and memory formation. J Neurosci 26:7919-7932. CrossRef Medline

Guzowski JF, Worley PF (2001) Cellular compartment analysis of temporal activity by fluorescence in situ hybridization (catFISH): current protocols in neuroscience/editorial board, Jacqueline N. Crawley [et al]. Chapter 1:Unit 1 8. CrossRef Medline

Helmstetter FJ, Parsons RG, Gafford GM (2008) Macromolecular synthesis, distributed synaptic plasticity, and fear conditioning. Neurobiol Learn Mem 89:324-337. CrossRef Medline

Hernandez PJ, Abel T (2008) The role of protein synthesis in memory consolidation: progress amid decades of debate. Neurobiol Learn Mem 89: 293-311. CrossRef Medline

Jeffrey RA, Ch'ng TH, O’Dell TJ, Martin KC (2009) Activity-dependent anchoring of importin $\alpha$ at the synapse involves regulated binding to the cytoplasmic tail of the NR1-1a subunit of the NMDA receptor. J Neurosci 29:15613-15620. CrossRef Medline

Klann E, Sweatt JD (2008) Altered protein synthesis is a trigger for longterm memory formation. Neurobiol Learn Mem 89:247-259. CrossRef Medline

Lai KO, Zhao Y, Ch'ng TH, Martin KC (2008) Importin-mediated retrograde transport of CREB2 from distal processes to the nucleus in neurons. Proc Natl Acad Sci U S A 105:17175-17180. CrossRef Medline

Lavaur J, Bernard F, Trifilieff P, Pascoli V, Kappes V, Pagès C, Vanhoutte P, Caboche J (2007) A TAT-DEF-Elk-1 peptide regulates the cytonuclear trafficking of Elk-1 and controls cytoskeleton dynamics. J Neurosci 27: 14448-14458. CrossRef Medline

Lee JA, Kim HK, Kim KH, Han JH, Lee YS, Lim CS, Chang DJ, Kubo T, Kaang BK (2001) Overexpression of and RNA interference with the CCAAT enhancer-binding protein on long-term facilitation of Aplysia sensory to motor synapses. Learn Mem 8:220-226. CrossRef Medline

Lein ES, Hawrylycz MJ, Ao N, Ayres M, Bensinger A, Bernard A, Boe AF, Boguski MS, Brockway KS, Byrnes EJ, et al. (2007) Genome-wide atlas of gene expression in the adult mouse brain. Nature 445:168-176. CrossRef Medline

Lewis DJ (1979) Psychobiology of active and inactive memory. Psychol Bull 86:1054-1083. CrossRef Medline

Lonze BE, Ginty DD (2002) Function and regulation of CREB family transcription factors in the nervous system. Neuron 35:605-623. CrossRef Medline

Martin KC, Zukin RS (2006) RNA trafficking and local protein synthesis in dendrites: an overview. J Neurosci 26:7131-7134. CrossRef Medline

McGaugh JL (2000) Memory: a century of consolidation. Science 287:248251. CrossRef Medline

Meffert MK, Chang JM, Wiltgen BJ, Fanselow MS, Baltimore D (2003) NF- $\kappa \mathrm{B}$ functions in synaptic signaling and behavior. Nat Neurosci 6:1072-1078. CrossRef Medline

Merhav M, Kuulmann-Vander S, Elkobi A, Jacobson-Pick S, Karni A, Rosenblum K (2006) Behavioral interference and C/EBP $\beta$ expression in the insular-cortex reveal a prolonged time period for taste memory consolidation. Learn Mem 13:571-574. CrossRef Medline

Milekic MH, Pollonini G, Alberini CM (2007) Temporal requirement of $\mathrm{C} / \mathrm{EBP} \beta$ in the amygdala following reactivation but not acquisition of inhibitory avoidance. Learn Mem 14:504-511. CrossRef Medline

Miniaci MC, Kim JH, Puthanveettil SV, Si K, Zhu H, Kandel ER, Bailey CH (2008) Sustained CPEB-dependent local protein synthesis is required to stabilize synaptic growth for persistence of long-term facilitation in Aplysia. Neuron 59:1024-1036. CrossRef Medline

Nader K, Hardt O (2009) A single standard for memory: the case for reconsolidation. Nat Rev Neurosci 10:224-234. CrossRef Medline

Ogita K, Okuda H, Kitano M, Fujinami Y, Ozaki K, Yoneda Y (2002) Localization of activator protein- 1 complex with DNA binding activity in mitochondria of murine brain after in vivo treatment with kainate. J Neurosci 22:2561-2570. Medline

Ou LC, Yeh SH, Gean PW (2010) Late expression of brain-derived neu- 
rotrophic factor in the amygdala is required for persistence of fear memory. Neurobiol Learn Mem 93:372-382. CrossRef Medline

Pohnke Y, Kempf R, Gellersen B (1999) CCAAT/enhancer-binding proteins are mediators in the protein kinase A-dependent activation of the decidual prolactin promoter. J Biol Chem 274:24808-24818. CrossRef Medline

Ramji DP, Foka P (2002) CCAAT/enhancer-binding proteins: structure, function and regulation. Biochem J 365:561-575. CrossRef Medline

Richter JD, Klann E (2009) Making synaptic plasticity and memory last: mechanisms of translational regulation. Genes Dev 23:1-11. CrossRef Medline

Silva AJ, Kogan JH, Frankland PW, Kida S (1998) CREB and memory. Annu Rev Neurosci 21:127-148. CrossRef Medline

Sterneck E, Paylor R, Jackson-Lewis V, Libbey M, Przedborski S, Tessarollo L, Crawley JN, Johnson PF (1998) Selectively enhanced contextual fear conditioning in mice lacking the transcriptional regulator CCAAT/enhancer binding protein $\delta$. Proc Natl Acad Sci U S A 95:10908-10913. CrossRef Medline

Suzuki A, Stern SA, Bozdagi O, Huntley GW, Walker RH, Magistretti PJ, Alberini CM (2011) Astrocyte-neuron lactate transport is required for long-term memory formation. Cell 144:810-823. CrossRef Medline

Suzuki T, Tian QB, Kuromitsu J, Kawai T, Endo S (2007) Characterization of mRNA species that are associated with postsynaptic density fraction by gene chip microarray analysis. Neurosci Res 57:61-85. CrossRef Medline

Taubenfeld SM, Milekic MH, Monti B, Alberini CM (2001a) The consolidation of new but not reactivated memory requires hippocampal C/EBP $\beta$. Nat Neurosci 4:813-818. CrossRef Medline

Taubenfeld SM, Wiig KA, Monti B, Dolan B, Pollonini G, Alberini CM (2001b) Fornix-dependent induction of hippocampal CCAAT enhancer-binding protein [beta] and [delta] co-localizes with phosphorylated cAMP response element-binding protein and accompanies long-term memory consolidation. J Neurosci 21:84-91. Medline
Taubenfeld SM, Riceberg JS, New AS, Alberini CM (2009) Preclinical assessment for selectively disrupting a traumatic memory via postretrieval inhibition of glucocorticoid receptors. Biol Psychiatry 65:249-257. CrossRef Medline

Thomas B, Berenbaum F, Humbert L, Bian H, Béréziat G, Crofford L, Olivier JL (2000) Critical role of C/EBP $\delta$ and $\mathrm{C} / \mathrm{EBP} \beta$ factors in the stimulation of the cyclooxygenase- 2 gene transcription by interleukin- $1 \beta$ in articular chondrocytes. Eur J Biochem 267:6798-6809. CrossRef Medline

Thompson KR, Otis KO, Chen DY, Zhao Y, O’Dell TJ, Martin KC (2004) Synapse to nucleus signaling during long-term synaptic plasticity: a role for the classical active nuclear import pathway. Neuron 44:997-1009. CrossRef Medline

Tronel S, Milekic MH, Alberini CM (2005) Linking new information to a reactivated memory requires consolidation and not reconsolidation mechanisms. PLoS Biol 3:e293. CrossRef Medline

Tsokas P, Grace EA, Chan P, Ma T, Sealfon SC, Iyengar R, Landau EM, Blitzer $\mathrm{RD}$ (2005) Local protein synthesis mediates a rapid increase in dendritic elongation factor $1 \mathrm{~A}$ after induction of late long-term potentiation. J Neurosci 25:5833-5843. CrossRef Medline

Whitlock JR, Heynen AJ, Shuler MG, Bear MF (2006) Learning induces long-term potentiation in the hippocampus. Science 313:1093-1097. CrossRef Medline

Wu CW, Zeng F, Eberwine J (2007) mRNA transport to and translation in neuronal dendrites. Anal Bioanal Chem 387:59-62. CrossRef Medline

Wu L, Wells D, Tay J, Mendis D, Abbott MA, Barnitt A, Quinlan E, Heynen A, Fallon JR, Richter JD (1998) CPEB-mediated cytoplasmic polyadenylation and the regulation of experience-dependent translation of $\alpha$-CaMKII mRNA at synapses. Neuron 21:1129-1139. CrossRef Medline

Yukawa K, Tanaka T, Tsuji S, Akira S (1998) Expressions of CCAAT/ enhancer-binding proteins $\beta$ and $\delta$ and their activities are intensified by cAMP signaling as well as $\mathrm{Ca}^{2+} /$ calmodulin kinases activation in hippocampal neurons. J Biol Chem 273:31345-31351. CrossRef Medline 